\title{
Geochemistry of surface sediments in tsunami-affected Sri Lankan lagoons regarding environmental implications
}

\author{
D. T. Jayawardana $\cdot$ H. Ishiga $\cdot$ H. M. T. G. A. Pitawala
}

Received: 18 January 2011/Revised: 25 June 2011/Accepted: 14 August 2011/Published online: 26 November 2011 (c) CEERS, IAU 2011

\begin{abstract}
The December 26, 2004 Indian Ocean tsunami was one of the largest in human history, devastating the coastal wetlands of surrounding countries. This study present the chemical analyses of tsunamigenic and pretsunami sediments from Hikkaduwa and Hambantota lagoons in southern Sri Lanka, to assess their geochemical composition, their source, and subsequent environmental impacts. Principal component analysis of the tsunami sediments shows that $42 \%$ of the total variance is accounted for calcium oxide and Sr. That is, the tsunami deposits are rich in biogenic phases derived from shallow marine sediments. High organic matter contents of the tsunami sediments of up to $80 \mathrm{wt} \%$ also support this interpretation. The association of chlorine $(<9.4 \mathrm{wt} \%)$, brome $(<170 \mathrm{mg} / \mathrm{kg})$, arsenic $(<17 \mathrm{mg} / \mathrm{kg})$, iron (III) oxide $(<12.9 \mathrm{wt} \%)$ and sulfur $(<7.6 \mathrm{wt} \%)$ accounts for $33 \%$ of the variance, reflecting higher salinity. This further suggests that the sediments were mainly derived from a marine environment, rather than from non-marine sands and/or soils. Immobile element contents and relations (thorium, scandium and zirconium) suggest that the tsunami sediment source was mostly felsic in composition, with some mafic component, and mixed with predominantly shallow marine shelf or slope sediments. Additional compositional variations in the tsunami sediments in both lagoons may be associated with variations of wave strength along the coast and by the morphology of the continental shelf. Lower
\end{abstract}

D. T. Jayawardana $(\bowtie) \cdot H$. Ishiga

Department of Geosciences, Graduate School of Science and Engineering, Shimane University, Matsue 690-8504, Japan e-mail: taranga23@yahoo.com

H. M. T. G. A. Pitawala

Department of Geology, Peradeniya University,

Peradeniya 20400, Sri Lanka elemental abundances in Hambantota lagoon sediments compared to Hikkaduwa equivalents may thus reflect a greater non-marine component in the former, and greater shelf sediment component in the latter.

Keywords Composition - Major elements - Total sulfur . Trace elements

\section{Introduction}

The major tsunami that was generated by a massive earthquake on December 26th 2004 struck many South Asian countries bordering the Bay of Bengal, and devastated the coastal regions of Sri Lanka. The tsunami waters over-ran $\sim 60 \%$ of the Sri Lankan coastline, and in some areas of flat topography inundation stretched $2-3 \mathrm{~km}$ inland. Extensive erosion, transportation of large volumes of marine sediments and subsequent deposition in coastal plains take place within a very short time during tsunami events. Field observations of tsunamigenic deposits have shown that they were generally characterized by presence of mafic mineral layers with landward fining of grain size and presence of shallow and/or deep sea fossils (Nishimura and Miyaji 1995; Shi et al. 1995; Moore et al. 2007; Paris et al. 2007). Well-sorted sands within black organic muds found in coastal wetlands have also identified as tsunami sediment sequences (Minoura et al. 1994). Recent geochemical investigations of 2004 tsunami sediments in Thailand found that content of salts and some trace metals was significantly elevated (Szczuciński et al. 2005). Tsunami sediments in wetlands were also characterized by higher $\mathrm{Fe}$ and/or sulfur values, along with higher organic matter contents (Goff and Chagué-Goff 1999). Higher abundances of $\mathrm{As}, \mathrm{Cl}, \mathrm{Br}, \mathrm{S}$ and organic matter in sedimentary sequences in some coastal wetland 
environments such as lagoons and marshy lands reflect the influences of tsunami and sea level changes on the coast (López-Buendía et al. 1999; Chagué-Goff et al. 2000, 2002). The presences of higher values of $\mathrm{Fe}, \mathrm{Sr}, \mathrm{Ca}$ and $\mathrm{S}$ have also been linked to lagoon subsidence associated with tsunami inundation (Nichol et al. 2007).

In Sri Lanka fine to medium-grained sand containing mafic minerals and deep sea fossils were identified from the recent tsunami sediments on the eastern, southern and southwestern coasts (Dahanayake and Kulasena 2008; Morton et al. 2008). The Sri Lankan coast contains many shallow small- and medium-scale lagoons that comprise important natural ecosystems. These were inundated during the tsunami, with widespread deposition of suspended sediment and debris (Morton et al. 2008; Yan and Tang 2009). However, as on today, no detailed studies of the geochemistry of tsunamigenic sediments in wetlands or the coastal plains of Sri Lanka have been made. Consequently, this study focuses on the geochemistry of the tsunami sediments in two lagoons (Hikkaduwa and Hambantota) situated on the southwestern and southern coast of Sri Lanka. Field survey for sample collection was carried out 18 months after the tsunami.

The geochemistry potentially provides valuable information on the nature and origin of the sediments and the effect of the tsunami on the environment. The results obtained may thus be useful for paleotsunami and paleoclimatic studies. The scope of the present study was to examine the major elements, trace elements and total sulfur of sediments in two tsunami-affected lagoons in order to (a) determine the chemical composition of the tsunami sediments; (b) identify their source; and (c) examine possible chemical changes that subsequently took place in the depositional environment.

\section{Study area and physical setting}

Hikkaduwa and Hambantota lagoons were situated on the southern coast of Sri Lanka, 100 and $250 \mathrm{~km}$ from the capital city of Colombo, respectively (Fig. 1). Both lagoons were inundated by massive tsunami waves. The tsunami sediments deposited within them were mainly associated with tsunami up-flow, rather than with reverse flow.

Hikkaduwa lagoon is a narrow north-west trending body located $1 \mathrm{~km}$ from the coastline. It has an area of about $2.5 \mathrm{~km}^{2}$ with maximum depth of $2 \mathrm{~m}$, and was connected to the sea through a narrow channel. The lagoon was widened by the tsunami, especially its northwestern corner (Fig. 1), due the action of strong tsunami waves about $7 \mathrm{~m}$ in height. Hambantota lagoon is a wider east-west trending lagoon, located half a kilometer from the coast. It has an area of about $3.5 \mathrm{~km}^{2}$ and water depth of $2.5 \mathrm{~m}$, and is also connected to the sea by a small channel. Heavy tsunami waves hit this coastal site, with maximum inundation height of around $7 \mathrm{~m}$. In general, the tidal ranges around both lagoons are low (mean annual tidal range $0.10-0.18 \mathrm{~m}$ ), and their narrow connections with the sea limit seawater influence within the lagoons (Wijeratne and Rydberg 2007; Wijeratne and Pattiaratchi-web reference). Average temperature at both sites is $30^{\circ} \mathrm{C}$ during the dry season (November-January), falling to around $20^{\circ} \mathrm{C}$ in the wet season (May-September).

The present setting of the coastal wetlands is a result of sea level changes during the Holocene period (Katupotha and Fujiwara 1988). The overburden cover in the area consists mainly of terrigenous sands, biogenic carbonates, and mud (Wijayananda 1994). Lateritic and peaty soils are also common (Dissanayake 1984). Basement rocks at both sites are mainly granulite facies charnockitic and granitic gneisses (Fig. 1) with lesser cordierite gneiss and garnet silimanite gneiss. The chemical composition of rocks in the region shows a bimodal distribution with a marked gap in $\mathrm{SiO}_{2}$ content between 57 and $62 \mathrm{wt} \%$, and significant enrichment of $\mathrm{Fe}_{2} \mathrm{O}_{3}, \mathrm{TiO}_{2}, \mathrm{MnO}, \mathrm{P}_{2} \mathrm{O}_{5}$ and $\mathrm{Sr}$ (Pohl and Emmermann 1991).

\section{Materials and methods}

Field survey and sample collection were carried out in both tsunami and pre-tsunami sites. Sample locations were selected based on field observations and information from local people who experienced the tsunami. Sample site selection considered the nature and extent of the tsunami deposits, inundation level, distance from the sea, and the geomorphology of the area.

Physical properties of lagoon water were studied with respect to depth using a drop-down electrode. Temperature, $\mathrm{pH}$, dissolved oxygen (DO), oxidation-reduction potential (ORP), total dissolved solids (TDS), turbidity, salinity, and conductivity were measured at different depths at each location, immediately prior to the collection of the sediment samples (Fig. 1).

Sediment samples were collected from inundated and non-inundated areas using a standard Ekman grab sampler. The sampler typically penetrated to a depth of $15 \mathrm{~cm}$, yielding a $3.5 \mathrm{~L}$ sample weighing about $7 \mathrm{~kg}$. Temperature, $\mathrm{ORP}$, and $\mathrm{pH}$ of each sample were measured at the time of collection. Textural characteristics of the sediment aggregates were estimated in the field using a texture chart. The surface fraction of the collected samples were stored in $10^{\circ} \mathrm{C}$ cool boxes and transferred to the laboratory.

The sediment samples were analyzed for major elements, trace elements and total sulfur by X-ray fluorescence spectrometry (RIX 2000) in the Department of 
Fig. 1 Maps of the study areas and location of sample sites. Filled circles denote pretsunami sediment samples, triangles denote tsunami sediments. Tsunami flow directions are indicated by arrows, heavy dashed lines are water inundation levels. Thinner dashed lines represent the locations of the schematic crosssections in Fig. 2
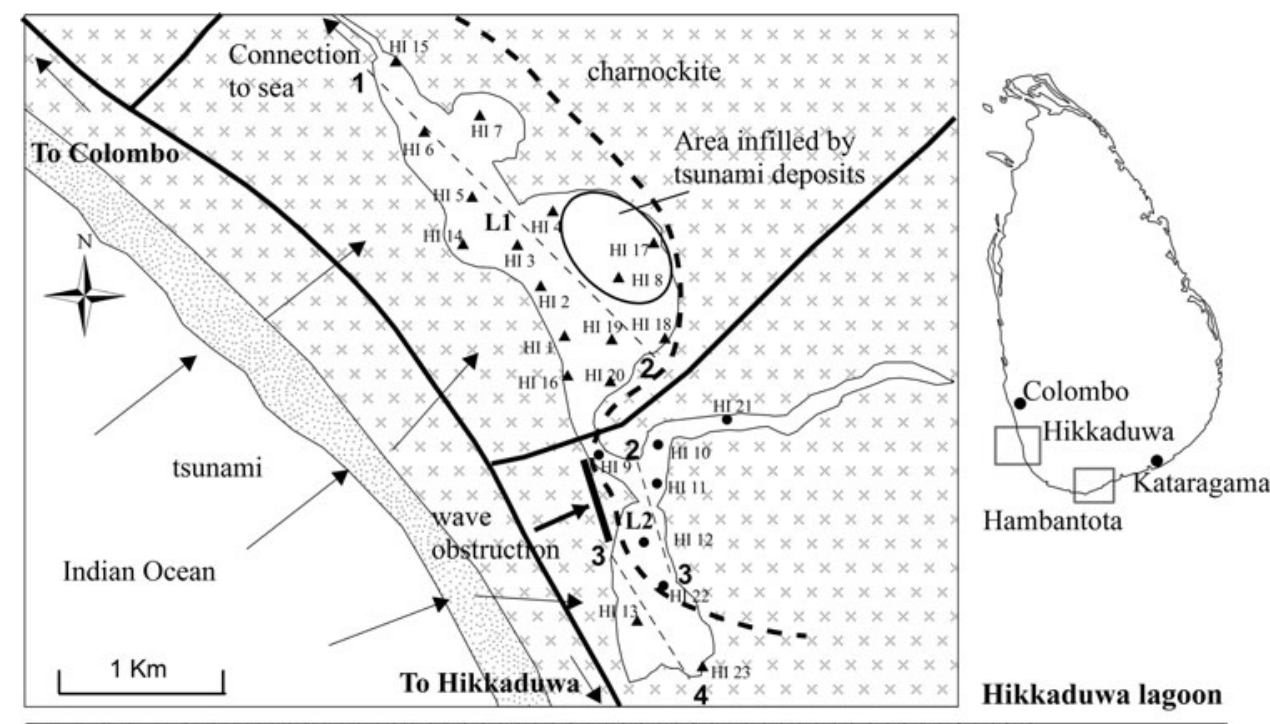

Hambantota

Hikkaduwa lagoon

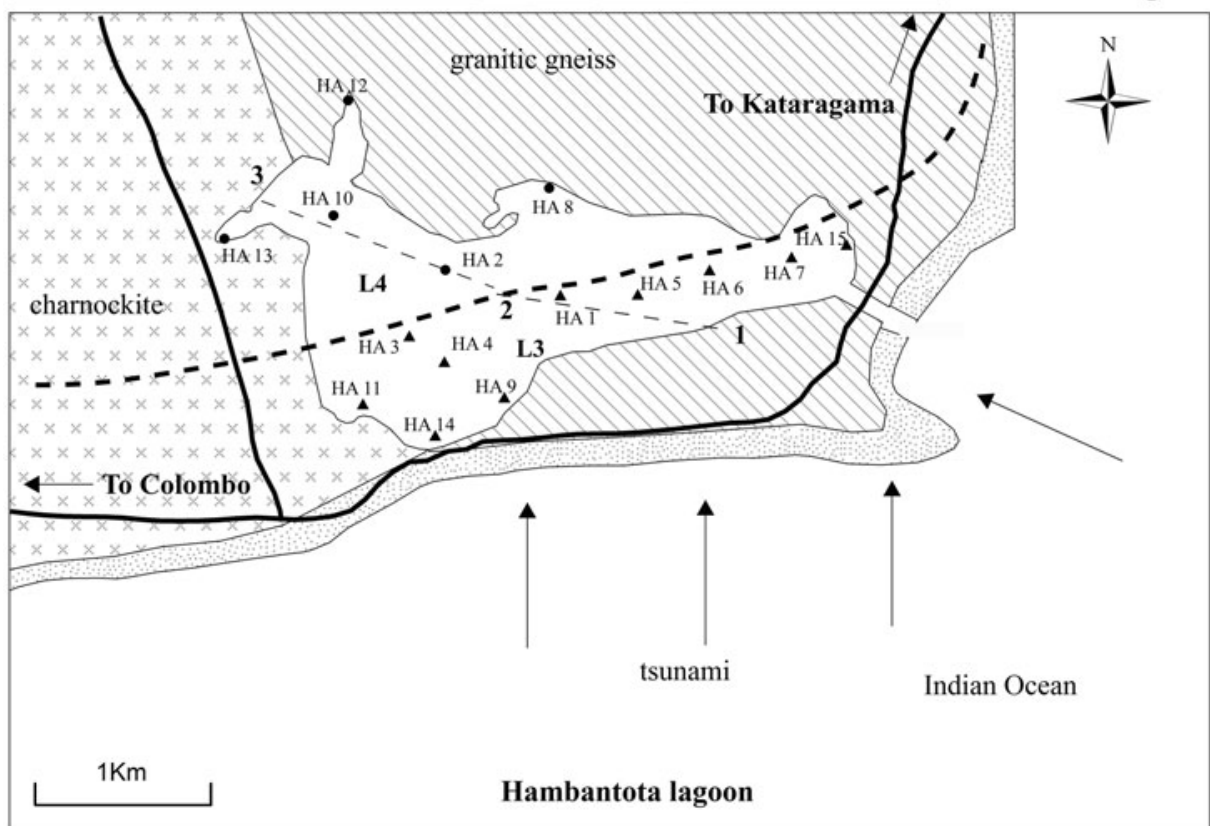

Geoscience at Shimane University. Gravimetric water was first removed by oven-drying for $24 \mathrm{~h} 110^{\circ} \mathrm{C}$. A split of each sample was then oven-dried for $48 \mathrm{~h}$ at $160^{\circ} \mathrm{C}$ to determine organic matter $(\mathrm{OM})$ content, the temperature limit $160^{\circ} \mathrm{C}$ to prevent the evaporation of carbonates, crushed the dried samples subsequently in an automatic agate pestle and mortar grinder. The crushed samples were then compressed into disk under a force of $200 \mathrm{KN}$ for $60 \mathrm{~s}$. The disk were subsequently analyzed for selected major elements $\left(\mathrm{TiO}_{2}, \mathrm{Fe}_{2} \mathrm{O}_{3}, \mathrm{MnO}, \mathrm{CaO}\right.$ and $\left.\mathrm{P}_{2} \mathrm{O}_{5}\right)$, trace elements (As, Pb, Zn, Cu, Ni, Cr, V, Sr, Y, Nb, Zr, Th, Sc, $\mathrm{Br}, \mathrm{I}$ and $\mathrm{Cl}$ ) and total sulfur (TS) under powder diffraction method. Average errors for these elements are less than $\pm 10 \%$.

Major and trace element data are key components of geochemical studies of sediments. Elemental normalization against upper continental crust (UCC) can assess the extent to which sediment compositions diverge from normal crustal composition (Taylor and McLennan 1985). Trace metal correlation with $\mathrm{Fe}_{2} \mathrm{O}_{3}$ and total sulfur are important relationships for studying the behavior of metals in the natural environment. $\mathrm{Fe}_{2} \mathrm{O}_{3}$ is typically positively correlated with most trace metals, but abundances may vary according to several factors such as $\mathrm{pH}$, ORP and anthropogenic impacts. It can, therefore, used to examine both the extent of contamination and the source of sediments (Ishiga et al. 2000; Gurung et al. 2005; Ahmed et al. 2005). Strong positive correlation between total sulfur and $\mathrm{Fe}_{2} \mathrm{O}_{3}$ indicates the temporary formation of pyrite within sediments (Berner 1970; Ishiga et al. 2000). Correlations between immobile element ratios are also useful for determining the source of sediments and the potential role of heavy mineral 
concentration (Bhatia and Crook 1986; McLennan et al. 1993; Roser 2000). Moreover, principle component analysis for the correlation matrix which obtained from geochemical data is useful to understand underlying data structure.

The nature of marine sediments provides a lever for the study of tsunami sediments, because, the geochemical composition of the latter is characterized by a largely physical mixture of lithological constitutents such as continental and oceanic detritus (Taylor and McLennan 1985; Othman et al. 1989; Plank and Langmuir 1998). The marine sediment around Sri Lanka comprises Bay of Bengal Fan sediment as described by Crowley et al. 1998 (see also Pattan and Shane 1999; Roonwal et al. 1997). Marine sediments also contain varying amounts of biogenic carbonate and opal, and consequently levels of elements such as $\mathrm{Ca}$ and $\mathrm{Sr}$ may be very high (Plank and Langmuir 1998). Abundances of $\mathrm{Cl}, \mathrm{Br}$ and total sulfur are also useful indicators of marine origin for sediments. In general, sulfur contents $>0.3 \mathrm{wt} \%$ indicates marine conditions (Berner 1970, 1982).

\section{Results and discussion}

\section{Water quality}

Average values of physico-chemical properties of water overlying OM-rich tsunami sediments and OM-poor pretsunami sediments were calculated for zones L1 and L2 (Hikkaduwa) and L3 and L4 (Hambantota) (Figs. 1, 2).
The surface undulation of the floors of both lagoons is very limited, and hence topography is almost flat.

The $\mathrm{pH}$, turbidity, DO and ORP of Hikkaduwa lagoon water ranges from 7.3 to $7.7,1$ to $37 \mathrm{NTU}, 0.7$ to $6.9 \mathrm{mg} / \mathrm{L}$ and 66 to $300 \mathrm{mV}$, respectively. Values of salinity, conductivity, TDS and temperature show little variation, and average $2.32 \%$, $3.56 \mathrm{mS} / \mathrm{cm}, 22 \mathrm{mg} / \mathrm{L}$ and $32^{\circ} \mathrm{C}$, respectively. The $\mathrm{pH}$ of the lagoon is neutral, and meets the United States Environmental Protection Agency (USEPA) criteria (6.5-9.0) for fresh water aquatic life. However, both $\mathrm{pH}$ and turbidity increase slightly towards the bottom (Table 1). ORP values were positive in the surface waters in both L1 and L2, but became more negative with depth. ORP values in L1 are abnormally low below $40 \mathrm{~cm}$, due to decomposition of OM. DO values were highest at the surface in both L1 and L2, and decrease slightly downward. DO values in the lagoon are below the USEPA and Canadian water quality guideline for early life stage ( $>6 \mathrm{mg} / \mathrm{L})$ and other life stages $(>5.5 \mathrm{mg} / \mathrm{L})$ in warm ecosystems.

Hambantota lagoon water is characterized by $\mathrm{pH}$, turbidity, DO and ORP values of 8.3-10.5, 2-60 NTU, $6.4-11.5 \mathrm{mg} / \mathrm{L}$ and $129-32 \mathrm{mV}$, respectively. Salinity, conductivity, TDS and temperature vary as in Hikkaduwa lagoon, but have lower average values of $1.18 \%, 2.04 \mathrm{mS} /$ $\mathrm{cm}, 13 \mathrm{mg} / \mathrm{L}$ and $30^{\circ} \mathrm{C}$, respectively. Turbidity and $\mathrm{pH}$ increase slightly toward the bottom of the lagoon, whereas ORP gradually decrease with depth in both L3 and L4 (Table 1). Average $\mathrm{pH}$ of Hambantota lagoon is above from the USEPA criteria (6.5-9.0) for fresh water aquatic life, because values at some sites slightly exceed the guideline. DO is generally above the USEPA recommended values for aquatic life stages.

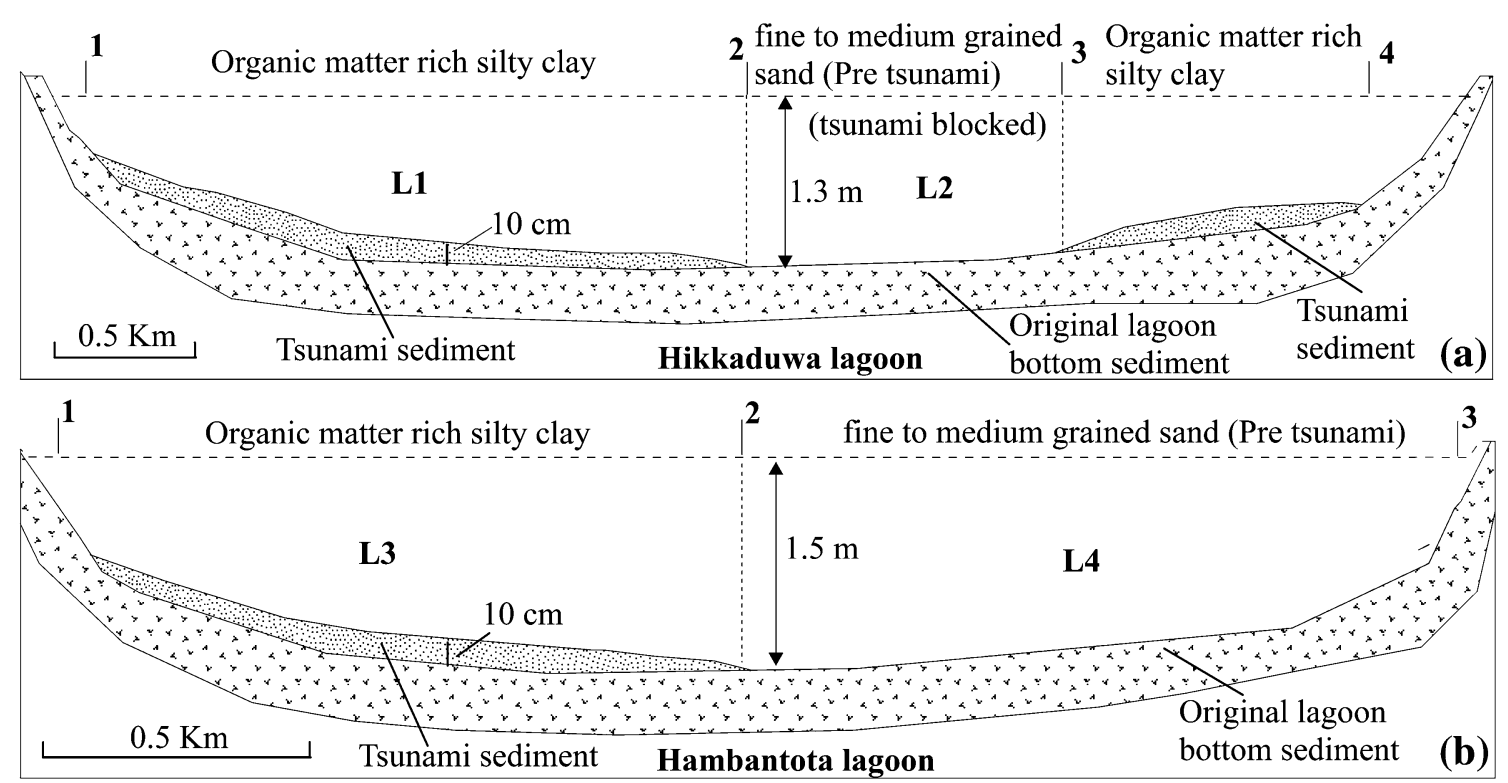

Fig. 2 Schematic cross-sections of Hikkaduwa and Hambantota lagoons 
Table 1 Average physico-chemical properties of the water bodies in Hikkaduwa and Hambantota lagoons

\begin{tabular}{|c|c|c|c|c|c|c|c|c|}
\hline Depth (m) & Temp $\left({ }^{\circ} \mathrm{C}\right)$ & $\mathrm{pH}$ & $\mathrm{EC}(\mathrm{mS} / \mathrm{cm})$ & Salinity (\%) & $\mathrm{DO}(\mathrm{mg} / \mathrm{L})$ & ORP $(\mathrm{mV})$ & Turbidity (NTU) & TDS (mg/L) \\
\hline \multicolumn{9}{|l|}{ Hikkaduwa } \\
\hline \multicolumn{9}{|l|}{ L 1} \\
\hline 0 & 32 & 7.5 & 3.56 & 2.25 & 4.4 & 49 & 10 & 22 \\
\hline 0.3 & 32 & 7.4 & 3.52 & 2.23 & 2.3 & 25 & 10 & 21 \\
\hline 0.4 & 31 & 7.4 & 3.33 & 2.02 & 2.6 & -289 & 15 & 20 \\
\hline 0.7 & 31 & 7.5 & 3.43 & 2.18 & 0.7 & -300 & 12 & 21 \\
\hline 0.8 & 32 & 7.6 & 3.55 & 2.25 & 1.0 & -230 & 16 & 24 \\
\hline 1.1 & 32 & 7.6 & 3.53 & 2.25 & 1.2 & -233 & 37 & 22 \\
\hline \multicolumn{9}{|l|}{ L 2} \\
\hline 0 & 33 & 7.5 & 3.58 & 2.27 & 5.5 & 66 & 9 & 22 \\
\hline 0.1 & 33 & 7.5 & 3.57 & 2.27 & 4.3 & 12 & 4 & 22 \\
\hline 0.4 & 33 & 7.3 & 3.75 & 3.25 & 6.8 & 20 & 3 & 23 \\
\hline 0.7 & 33 & 7.7 & 3.72 & 2.37 & 6.9 & 12 & 3 & 23 \\
\hline 1.2 & 32 & 7.7 & 3.58 & 2.27 & 2.7 & -15 & 1 & 22 \\
\hline 1.3 & 32 & 7.7 & 3.59 & 2.28 & 1.3 & -70 & 6 & 22 \\
\hline Avg & 32 & 7.5 & 3.56 & 2.32 & 3.3 & -79 & 11 & 22 \\
\hline Min & 31 & 7.3 & 3.33 & 2.02 & 0.7 & -300 & 1 & 20 \\
\hline $\operatorname{Max}$ & 33 & 7.7 & 3.75 & 3.25 & 6.9 & 66 & 37 & 24 \\
\hline \multicolumn{9}{|c|}{ Hambantota } \\
\hline \multicolumn{9}{|l|}{ L 3} \\
\hline 0 & 29 & 9.0 & 1.71 & 1.01 & 7.3 & 29 & 20 & 11 \\
\hline 0.3 & 30 & 9.6 & 2.06 & 1.22 & 9.9 & 20 & 6 & 12 \\
\hline 0.5 & 31 & 9.4 & 2.70 & 1.19 & 11.5 & 12 & 20 & 12 \\
\hline 0.6 & 31 & 10.5 & 2.13 & 1.29 & 10.7 & 8 & 16 & 13 \\
\hline 1.1 & 32 & 10.0 & 2.19 & 1.28 & 9.8 & 11 & 24 & 13 \\
\hline 1.2 & 30 & 9.9 & 2.05 & 1.24 & 11.4 & -12 & 21 & 17 \\
\hline 1.5 & 31 & 10.0 & 2.14 & 1.30 & 11.3 & -32 & 60 & 13 \\
\hline \multicolumn{9}{|l|}{ L 4} \\
\hline 0 & 31 & 9.3 & 2.15 & 1.31 & 9.6 & 129 & 12 & 13 \\
\hline 0.5 & 30 & 8.3 & 1.71 & 1.01 & 6.5 & 80 & 3 & 11 \\
\hline 0.8 & 29 & 8.6 & 1.71 & 1.01 & 6.4 & 75 & 3 & 11 \\
\hline 1.0 & 30 & 9.8 & 2.19 & 1.33 & 10.6 & 27 & 20 & 14 \\
\hline 1.5 & 30 & 8.9 & 1.73 & 1.02 & 6.6 & 11 & 2 & 11 \\
\hline Avg & 30 & 9.4 & 2.04 & 1.18 & 9.3 & 30 & 17 & 13 \\
\hline Min & 29 & 8.3 & 1.71 & 1.01 & 6.4 & -32 & 2 & 11 \\
\hline Max & 32 & 10.5 & 2.70 & 1.33 & 11.5 & 129 & 60 & 17 \\
\hline
\end{tabular}

Each value is the average of three measurements

$L 1$ area with highly organic mud, $L 2$ area with sandy sediments, $L 3$ area with silt clays, $L 4$ area with sandy sediments

\section{Textural characteristics of sediments}

The tsunami sediment deposits in both lagoons are continuous, with thicknesses varying from a few centimeters to a few tens of centimeters. Thickness varies due to distance from the sea, undulation of the lagoon morphology, level of inundation, and wave strength. Landward fining of sediments was noted during field observation. In general, the sediments are overlaying by thin fine-grained gray silts and clays containing mafic minerals. These silts and clays may represent suspension fallout from the floodwaters.

Based on their textural characteristics, the sediments in Hikkaduwa lagoon can be divided into two categories (Fig. 2a). The central part of the lagoon predominantly consists of medium-grained sand deposits reflect the pretsunami sediments. The corners of the lagoon and an area infilled by the tsunami consist of black colored silts and clays. The amount of sand and volume of shell material 
Table 2 Major oxide abundances and physico-chemical conditions of Hikkaduwa and Hambantota lagoon sediments

\begin{tabular}{|c|c|c|c|c|c|c|c|c|c|c|}
\hline \multirow[t]{2}{*}{ Sample ID } & \multirow[t]{2}{*}{ Remark } & \multirow[t]{2}{*}{ Lithology } & \multirow[t]{2}{*}{$\mathrm{pH}$} & \multirow[t]{2}{*}{$\mathrm{ORP}(\mathrm{mV})$} & \multirow[t]{2}{*}{$\mathrm{OM}(\mathrm{wt} \%)$} & \multicolumn{5}{|c|}{ Major oxides (wt\%) } \\
\hline & & & & & & $\mathrm{TiO}_{2}$ & $\mathrm{Fe}_{2} \mathrm{O}_{3}$ & $\mathrm{MnO}$ & $\mathrm{CaO}$ & $\mathrm{P}_{2} \mathrm{O}_{5}$ \\
\hline \multicolumn{11}{|l|}{ Hikkaduwa } \\
\hline HI 1 & $\mathrm{~T}$ & $\mathrm{SC}$ & 7.0 & -300 & 58 & 0.62 & 6.72 & 0.01 & 6.28 & 0.09 \\
\hline HI 2 & $\mathrm{~T}$ & $\mathrm{SC}$ & 6.8 & -347 & 63 & 0.24 & 4.60 & 0.01 & 8.84 & 0.12 \\
\hline HI 3 & $\mathrm{~T}$ & $\mathrm{SC}$ & 6.9 & -360 & 79 & 0.60 & 12.57 & 0.02 & 3.31 & 0.10 \\
\hline HI 4 & $\mathrm{~T}$ & $\mathrm{SC}$ & 6.7 & -320 & 78 & 0.47 & 11.52 & 0.01 & 4.27 & 0.14 \\
\hline HI 5 & $\mathrm{~T}$ & $\mathrm{SC}$ & 6.8 & -370 & 74 & 0.42 & 8.43 & 0.02 & 7.59 & 0.15 \\
\hline HI 6 & $\mathrm{~T}$ & $\mathrm{SC}$ & 6.9 & -364 & 80 & 0.60 & 12.99 & 0.03 & 3.22 & 0.10 \\
\hline HI 7 & $\mathrm{~T}$ & $\mathrm{SC}$ & 6.7 & -350 & 70 & 0.32 & 8.14 & 0.02 & 7.89 & 0.24 \\
\hline HI 8 & $\mathrm{~T}$ & $\mathrm{SC}$ & 6.8 & -330 & 66 & 0.48 & 6.31 & 0.01 & 7.72 & 0.16 \\
\hline HI 13 & $\mathrm{~T}$ & $\mathrm{SC}$ & 6.9 & -380 & 71 & 1.64 & 1.92 & 0.01 & 26.91 & 0.13 \\
\hline HI 14 & $\mathrm{~T}$ & $\mathrm{SC}$ & - & - & 69 & 0.38 & 6.00 & 0.01 & 13.50 & 0.15 \\
\hline HI 15 & $\mathrm{~T}$ & $\mathrm{SC}$ & - & - & 66 & 0.37 & 3.29 & & 9.05 & 0.08 \\
\hline HI 16 & $\mathrm{~T}$ & $\mathrm{SC}$ & - & - & 66 & 0.79 & 11.08 & 0.02 & 2.01 & 0.10 \\
\hline HI 17 & $\mathrm{~T}$ & $\mathrm{SC}$ & - & - & 64 & 0.46 & 7.66 & 0.01 & 18.34 & 0.17 \\
\hline HI 18 & $\mathrm{~T}$ & $\mathrm{SC}$ & - & - & 67 & 0.68 & 4.92 & 0.01 & 8.54 & 0.12 \\
\hline HI 19 & $\mathrm{~T}$ & $\mathrm{SC}$ & - & - & 65 & 0.32 & 2.94 & & 13.53 & 0.15 \\
\hline HI 20 & $\mathrm{~T}$ & SA & - & - & 61 & 0.30 & 3.97 & & 2.39 & 0.21 \\
\hline \multirow[t]{4}{*}{ HI 23} & $\mathrm{~T}$ & $\mathrm{SC}$ & - & - & 72 & 0.50 & 5.68 & 0.01 & 8.37 & 0.15 \\
\hline & T-Avg & & 6.8 & -347 & 69 & 0.54 & 6.98 & 0.01 & 8.93 & 0.14 \\
\hline & Min & & 6.7 & -380 & 58 & 0.24 & 1.92 & 0.01 & 2.01 & 0.08 \\
\hline & Max & & 7.0 & -300 & 80 & 1.64 & 12.99 & 0.03 & 26.91 & 0.24 \\
\hline HI 9 & $\mathrm{Pt}$ & $\mathrm{SA}$ & 6.6 & -340 & 33 & 0.24 & 0.76 & & 10.95 & 0.07 \\
\hline HI 10 & $\mathrm{Pt}$ & SA & 6.7 & -350 & 25 & 0.59 & 7.82 & 0.01 & 5.06 & 0.13 \\
\hline HI 11 & $\mathrm{Pt}$ & SA & 6.9 & -365 & 30 & 1.54 & 1.59 & 0.01 & 8.24 & 0.08 \\
\hline HI 12 & $\mathrm{Pt}$ & $\mathrm{SC}$ & 6.8 & -357 & 35 & 0.94 & 1.47 & 0.01 & 21.54 & 0.12 \\
\hline HI 21 & $\mathrm{Pt}$ & SA & - & - & 27 & 0.52 & 7.96 & 0.01 & 2.81 & 0.43 \\
\hline \multirow[t]{4}{*}{ HI 22} & $\mathrm{Pt}$ & $\mathrm{SC}$ & - & - & 38 & 0.38 & 5.87 & 0.01 & 8.90 & 0.18 \\
\hline & Pt-Avg & & 6.8 & -353 & 31 & 0.70 & 4.25 & 0.01 & 9.58 & 0.17 \\
\hline & Min & & 6.6 & -365 & 25 & 0.24 & 0.76 & 0.01 & 2.81 & 0.07 \\
\hline & $\operatorname{Max}$ & & 6.9 & -340 & 38 & 1.54 & 7.96 & 0.01 & 21.54 & 0.43 \\
\hline \multicolumn{11}{|l|}{ Hambantota } \\
\hline HA 1 & $\mathrm{~T}$ & $\mathrm{SC}$ & 7.8 & -83 & 44 & 0.61 & 3.66 & 0.09 & 14.08 & 0.14 \\
\hline HA 3 & $\mathrm{~T}$ & $\mathrm{SC}$ & 7.5 & -297 & 50 & 0.72 & 10.12 & 0.20 & 7.02 & 0.18 \\
\hline HA 4 & $\mathrm{~T}$ & $\mathrm{SC}$ & 7.7 & -350 & 46 & 0.71 & 3.93 & 0.08 & 7.89 & 0.16 \\
\hline HA 5 & $\mathrm{~T}$ & $\mathrm{SC}$ & 7.2 & -300 & 49 & 0.63 & 7.51 & 0.18 & 6.32 & 0.19 \\
\hline HA 6 & $\mathrm{~T}$ & SA & 7.9 & -380 & 34 & 0.68 & 2.94 & 0.06 & 11.62 & 0.20 \\
\hline HA 7 & $\mathrm{~T}$ & $\mathrm{SA}$ & 7.5 & -266 & 39 & 0.81 & 2.86 & 0.06 & 7.31 & 0.18 \\
\hline HA 9 & $\mathrm{~T}$ & SA & - & - & 35 & 0.52 & 3.05 & 0.04 & 9.08 & 0.18 \\
\hline HA 11 & $\mathrm{~T}$ & $\mathrm{SC}$ & - & - & 40 & 0.61 & 2.98 & 0.04 & 6.33 & 0.16 \\
\hline HA 14 & $\mathrm{~T}$ & $\mathrm{SA}$ & - & - & 38 & 0.52 & 3.05 & 0.04 & 9.08 & 0.18 \\
\hline \multirow[t]{4}{*}{ HA 15} & $\mathrm{~T}$ & $\mathrm{SA}$ & - & - & 42 & 0.81 & 2.86 & 0.06 & 7.31 & 0.18 \\
\hline & T-Avg & & 7.6 & -279 & 42 & 0.66 & 4.30 & 0.09 & 8.60 & 0.18 \\
\hline & Min & & 7.2 & -380 & 34 & 0.52 & 2.86 & 0.04 & 6.32 & 0.14 \\
\hline & Max & & 7.9 & -83 & 50 & 0.81 & 10.12 & 0.20 & 14.08 & 0.20 \\
\hline HA 2 & $\mathrm{Pt}$ & $\mathrm{SC}$ & 7.4 & -363 & 30 & 0.64 & 5.02 & 0.19 & 11.28 & 0.18 \\
\hline HA 8 & $\mathrm{Pt}$ & $\mathrm{SC}$ & - & - & 25 & 0.47 & 2.97 & 0.03 & 5.13 & 0.18 \\
\hline HA 10 & $\mathrm{Pt}$ & $\mathrm{SC}$ & - & - & 27 & 0.68 & 2.83 & 0.05 & 6.31 & 0.19 \\
\hline
\end{tabular}


Table 2 continued

\begin{tabular}{|c|c|c|c|c|c|c|c|c|c|c|}
\hline \multirow[t]{2}{*}{ Sample ID } & \multirow[t]{2}{*}{ Remark } & \multirow[t]{2}{*}{ Lithology } & \multirow[t]{2}{*}{$\mathrm{pH}$} & \multirow[t]{2}{*}{ ORP (mV) } & \multirow[t]{2}{*}{$\mathrm{OM}(\mathrm{wt} \%)$} & \multicolumn{5}{|c|}{ Major oxides (wt\%) } \\
\hline & & & & & & $\mathrm{TiO}_{2}$ & $\mathrm{Fe}_{2} \mathrm{O}_{3}$ & $\mathrm{MnO}$ & $\mathrm{CaO}$ & $\mathrm{P}_{2} \mathrm{O}_{5}$ \\
\hline HA 12 & $\mathrm{Pt}$ & $\mathrm{SC}$ & - & - & 26 & 0.68 & 2.83 & 0.05 & 6.31 & 0.19 \\
\hline \multirow[t]{4}{*}{ HA 13} & $\mathrm{Pt}$ & $\mathrm{SC}$ & - & - & 20 & 0.68 & 2.83 & 0.05 & 6.31 & 0.19 \\
\hline & Pt-Avg & & 7.4 & -363 & 26 & 0.63 & 3.30 & 0.07 & 7.07 & 0.19 \\
\hline & Min & & & & 20 & 0.47 & 2.83 & 0.03 & 5.13 & 0.18 \\
\hline & $\operatorname{Max}$ & & & & 30 & 0.68 & 5.02 & 0.19 & 11.28 & 0.19 \\
\hline
\end{tabular}

$T$ tsunami, $P t$ pre-tsunami, $O M$ organic matter, $S C$ silt and clay, $S A$ sand

thus decreases from the middle of the lagoon towards the corners. Hambantota lagoon tsunami sediment deposits present clear contrast (Fig. 2b), with grain size decreasing with increasing distance from the sea. The lagoon floor near the coastline is covered by brown colored fine-grained sands containing copious shell material, and a lesser amount of organic matter. However, the proportion of OMrich black colored silt and clay increases toward the center of the lagoon. According to the field observations pretsunami sediments in the lagoon consists of fine to medium-grained sandy muds.

Chemical characteristics of the sediments

The OM contents of Hikkaduwa tsunami sediments are characteristically greater (58-80 wt \%; average $69 \mathrm{wt} \%)$ than in Hambantota lagoon equivalents (34-50 wt \%, average $42 \mathrm{wt} \%$ ). However, pre-tsunami sediment samples in both lagoons have lower values (Hikkaduwa 25-38 wt \%; Hambantota $20-30 \mathrm{wt} \%$, Table 2), with an overall average of $29 \mathrm{wt} \%$. Because those sediments are predominantly reflect weathering component of the basement. The values of onsite physico-chemical measurements of the sediments are given in Table 2 . The sediments are generally characterized by neutral $\mathrm{pH}(6.6-7.9)$ and negative ORP ( -83 to $-380 \mathrm{mV}$ ).

The analyzed samples are characterized by wide ranges of $\mathrm{Fe}_{2} \mathrm{O}_{3}(0.76-12.99 \mathrm{wt} \%)$ and $\mathrm{CaO}(2.01-26.91 \mathrm{wt} \%)$ contents. The tsunami sediments are differentiated by higher values of both oxides (Table 2). However, abundances of $\mathrm{MnO}, \mathrm{P}_{2} \mathrm{O}_{5}$ and $\mathrm{TiO}_{2}$ in the tsunami and pretsunami sediments do not differ greatly (Table 2). The tsunami sediments are relatively enriched in chalcophile elements $(\mathrm{As}, \mathrm{Pb}, \mathrm{Zn}$ and $\mathrm{Cu})$, although contents are more variable (Table 3). Arsenic concentrations in Hikkaduwa lagoon sediments are consistently greater than in Hambantota, but $\mathrm{Zn}, \mathrm{Pb}$ and $\mathrm{Cu}$ values are similar in both lagoons. Abundances of ferromagnesian elements $(\mathrm{Ni}, \mathrm{Cr}$, $\mathrm{V}$ and $\mathrm{Sc}$ ) and large cations ( $\mathrm{Y}, \mathrm{Nb}, \mathrm{Zr}$, Th and $\mathrm{Sr}$ ) also tend to be higher in tsunami sediments than in the pretsunami sediments (Table 3). In some tsunami sediments
Sr concentrations are exceptionally high $(>1,000 \mathrm{mg} / \mathrm{kg})$, but the average value is very similar to that in the pretsunami samples.

Concentrations of $\mathrm{Cl}, \mathrm{Br}, \mathrm{I}$ and total sulfur (TS) are highly elevated in both lagoons, characteristically in the tsunami sediments. As for other elements, overall average abundances of $\mathrm{Cl}, \mathrm{Br}$, I and TS in Hikkaduwa lagoon (3.9 wt $\%, 74.5 \mathrm{mg} / \mathrm{kg}, 13.7 \mathrm{mg} / \mathrm{kg}, 4.4 \mathrm{wt} \%$, respectively) are also greater than in Hambantota lagoon (1.7 wt\%, 25.1 $\mathrm{mg} / \mathrm{kg}, 17.8 \mathrm{mg} / \mathrm{kg}, 1.8 \mathrm{wt} \%)$.

Comparison with possible sources

Average contents of $\mathrm{TiO}_{2}, \mathrm{Fe}_{2} \mathrm{O}_{3}$, and $\mathrm{P}_{2} \mathrm{O}_{5}$ in tsunami and pre-tsunami sediments in both lagoons are similar to those in average upper continental crust (Rudnick and Gao 2005) and the basement rocks in the area (Fig. 3a). $\mathrm{MnO}$ is strongly depleted in Hikkaduwa lagoon, whereas the average in Hambantota lagoon is comparable to UCC. $\mathrm{CaO}$ and $\mathrm{Sr}$ are slightly enriched in both lagoons relative to UCC. Arsenic is enriched in Hikkaduwa lagoon tsunami sediments, whereas in Hambantota lagoon it is slightly depleted (Fig. 3a). In both lagoons average contents of $\mathrm{Pb}$, $\mathrm{Zn}, \mathrm{Cu}, \mathrm{Ni}, \mathrm{Cr}$ and $\mathrm{V}$ are depleted relative to UCC, but follow similar patterns to the basement rocks (Fig. 5a). Yttrium is slightly depleted, in contrast to relative enrichment in the basement rocks. Average abundances of $\mathrm{Nb}$ and $\mathrm{Zr}$ are similar to UCC but are slightly depleted relative to the basement rocks. Thorium is slightly depleted in Hambantota lagoon sediments, but the Hikkaduwa average is similar to that of the basement rocks. Abundances of $\mathrm{Cl}$, $\mathrm{Br}$ and I are strongly enriched, with values tenfold those of crustal values (Fig. 3a). Normalization of average values in the tsunami sediments against the pre-tsunami average (Fig. 3b) shows that $\mathrm{Fe}_{2} \mathrm{O}_{3}, \mathrm{As}, \mathrm{Pb}, \mathrm{Zn}, \mathrm{Cu}, \mathrm{Ni}, \mathrm{Cr}, \mathrm{V}, \mathrm{Sr}$, $\mathrm{Y}, \mathrm{Th}, \mathrm{Sc}$ and $\mathrm{Br}$ are enriched in the former, whereas $\mathrm{Zr}$, $\mathrm{TiO}_{2}, \mathrm{P}_{2} \mathrm{O}_{5}, \mathrm{Nb}$ and iodine are somewhat depleted. This suggests that the tsunami sediments reflect marine influence, and contain significant amounts of ferromagnesian heavy minerals rather than resistant heavy minerals such as zirconium, apatite and rutile. 
Table 3 Trace element abundances in Hikkaduwa and Hambantota lagoon sediments

\begin{tabular}{|c|c|c|c|c|c|c|c|c|c|c|c|c|c|c|c|c|c|c|c|}
\hline \multirow[t]{2}{*}{ Sample ID } & \multirow[t]{2}{*}{ Remark } & \multirow[t]{2}{*}{ Lithology } & \multicolumn{15}{|c|}{ Trace element (mg/kg) } & \multicolumn{2}{|c|}{$(\mathrm{wt} \%)$} \\
\hline & & & As & $\mathrm{Pb}$ & $\mathrm{Zn}$ & $\mathrm{Cu}$ & $\mathrm{Ni}$ & $\mathrm{Cr}$ & $\mathrm{V}$ & $\mathrm{Sr}$ & $\mathrm{Y}$ & $\mathrm{Nb}$ & $\mathrm{Zr}$ & Th & $\mathrm{Sc}$ & $\mathrm{Br}$ & I & $\mathrm{Cl}$ & $\mathrm{TS}$ \\
\hline \multicolumn{20}{|l|}{ Hikkaduwa } \\
\hline HI 1 & $\mathrm{~T}$ & $\mathrm{SC}$ & 9 & 13 & 41 & 6 & 10 & 78 & 84 & 306 & 11 & 15 & 271 & 16 & 8 & 49 & 16 & 2.0 & 4.0 \\
\hline HI 2 & $\mathrm{~T}$ & $\mathrm{SC}$ & 9 & 12 & 29 & 5 & 5 & 75 & 39 & 392 & 7 & 4 & 123 & 10 & 8 & 49 & 19 & 3.2 & 3.4 \\
\hline HI 3 & $\mathrm{~T}$ & $\mathrm{SC}$ & 15 & 17 & 80 & 9 & 21 & 104 & 139 & 175 & 18 & 12 & 235 & 20 & 7 & 89 & 7 & 5.1 & 4.7 \\
\hline HI 4 & $\mathrm{~T}$ & $\mathrm{SC}$ & 12 & 17 & 79 & 11 & 14 & 65 & 103 & 319 & 13 & 11 & 168 & 16 & 5 & 115 & & 7.8 & 7.6 \\
\hline HI 5 & $\mathrm{~T}$ & $\mathrm{SC}$ & 11 & 15 & 67 & 9 & 12 & 61 & 75 & 394 & 12 & 11 & 178 & 14 & 9 & 117 & 10 & 7.3 & 5.5 \\
\hline HI 6 & $\mathrm{~T}$ & $\mathrm{SC}$ & 17 & 17 & 88 & 10 & 23 & 106 & 136 & 169 & 19 & 12 & 208 & 21 & 7 & 103 & 10 & 5.6 & 4.6 \\
\hline HI 7 & $\mathrm{~T}$ & $\mathrm{SC}$ & 12 & 21 & 88 & 14 & 12 & 53 & 66 & 486 & 11 & 7 & 89 & 13 & 10 & 158 & 4 & 9.4 & 6.0 \\
\hline HI 8 & $\mathrm{~T}$ & $\mathrm{SC}$ & 9 & 16 & 59 & 8 & 11 & 62 & 64 & 425 & 9 & 11 & 184 & 14 & 8 & 73 & 22 & 3.9 & 4.7 \\
\hline HI 13 & $\mathrm{~T}$ & $\mathrm{SC}$ & 8 & 14 & 38 & 5 & 0 & 64 & 133 & 1,290 & 8 & 43 & 920 & 31 & 19 & 14 & & 1.7 & 1.7 \\
\hline HI 14 & $\mathrm{~T}$ & SC & 11 & 12 & 44 & 7 & 6 & 52 & 60 & 884 & 11 & 9 & & 12 & 12 & 65 & & 3.4 & 5.1 \\
\hline HI 15 & $\mathrm{~T}$ & $\mathrm{SC}$ & 7 & 10 & 25 & 4 & 5 & 58 & 28 & 335 & 6 & 9 & 202 & 11 & 9 & 31 & 20 & 1.6 & 2.9 \\
\hline HI 16 & $\mathrm{~T}$ & SA & 15 & 17 & 83 & 9 & 25 & 117 & 147 & 105 & 19 & 19 & 404 & 24 & 8 & 71 & 13 & 2.9 & 4.0 \\
\hline HI 17 & $\mathrm{~T}$ & $\mathrm{SC}$ & 16 & 14 & 50 & 8 & 8 & 68 & 79 & 1,189 & 15 & 11 & 206 & 19 & 17 & 84 & & 1.5 & 4.7 \\
\hline HI 18 & $\mathrm{~T}$ & $\mathrm{SC}$ & 9 & 12 & 31 & 6 & 7 & 80 & 68 & 370 & 9 & 16 & 273 & 14 & 7 & 28 & 15 & 0.6 & 4.6 \\
\hline HI 19 & $\mathrm{~T}$ & $\mathrm{SC}$ & 10 & 10 & 16 & 6 & 5 & 68 & 44 & 512 & 6 & 7 & 119 & 10 & 11 & 43 & 16 & 3.1 & 3.5 \\
\hline HI 20 & $\mathrm{~T}$ & SA & 8 & 16 & 23 & 8 & 18 & 45 & 54 & 144 & 8 & 8 & 143 & 8 & 2 & 170 & 13 & 7.3 & 5.5 \\
\hline \multirow[t]{4}{*}{ HI 23} & $\mathrm{~T}$ & $\mathrm{SC}$ & 12 & 13 & 35 & 7 & 12 & 53 & 68 & 467 & 10 & 12 & 175 & 13 & 9 & 79 & 6 & 3.3 & 5.6 \\
\hline & T-Avg & & 11 & 14 & 52 & 8 & 11 & 71 & 82 & 468 & 11 & 13 & 244 & 16 & 9 & 79 & 13 & 4.1 & 4.6 \\
\hline & Min & & 7 & 10 & 16 & 4 & 0 & 45 & 28 & 105 & 6 & 4 & 89 & 8 & 2 & 14 & 4 & 0.6 & 1.7 \\
\hline & Max & & 17 & 21 & 88 & 14 & 25 & 117 & 147 & 1,290 & 19 & 43 & 920 & 31 & 19 & 170 & 22 & 9.4 & 7.6 \\
\hline HI 9 & $\mathrm{Pt}$ & SA & 3 & 8 & 8 & 2 & 0 & 53 & 0 & 383 & 3 & 4 & 132 & 4 & 7 & 13 & 30 & 1.6 & 1.0 \\
\hline HI 10 & $\mathrm{Pt}$ & SA & 9 & 14 & 48 & 9 & 12 & 59 & 76 & 328 & 11 & 14 & 281 & 16 & 5 & 111 & 5 & 6.9 & 6.3 \\
\hline HI 11 & $\mathrm{Pt}$ & SA & 4 & 11 & 39 & 2 & 4 & 84 & 125 & 286 & 5 & 31 & 703 & 20 & 8 & 16 & 20 & 2.0 & 1.7 \\
\hline HI 12 & $\mathrm{Pt}$ & $\mathrm{SC}$ & 5 & 12 & 24 & 5 & 1 & 47 & 59 & 1,027 & 5 & 22 & 450 & 12 & 15 & 27 & 7 & 2.6 & 2.0 \\
\hline HI 21 & $\mathrm{Pt}$ & SA & 11 & 17 & 55 & 8 & 20 & 73 & 95 & 156 & 15 & 12 & 257 & 15 & 4 & 108 & 13 & 5.2 & 5.8 \\
\hline \multirow[t]{4}{*}{ HI 22} & $\mathrm{Pt}$ & $\mathrm{SC}$ & 10 & 13 & 38 & 7 & 13 & 45 & 59 & 622 & 11 & 9 & 93 & 11 & 9 & 97 & & 4.1 & 5.9 \\
\hline & Pt-Avg & & 7 & 13 & 35 & 6 & 8 & 60 & 69 & 467 & 8 & 15 & 319 & 13 & 8 & 62 & 15 & 3.7 & 3.8 \\
\hline & Min & & 3 & 8 & 8 & 2 & 0 & 45 & 0 & 156 & 3 & 4 & 93 & 4 & 4 & 13 & 5 & 1.6 & 1.0 \\
\hline & Max & & 11 & 17 & 55 & 9 & 20 & 84 & 125 & 1,027 & 15 & 31 & 703 & 20 & 15 & 111 & 30 & 6.9 & 6.3 \\
\hline \multicolumn{20}{|l|}{ Hambantota } \\
\hline HA 1 & $\mathrm{~T}$ & $\mathrm{SC}$ & 3 & 13 & 51 & 10 & 10 & 64 & 71 & 603 & 18 & 11 & 156 & 8 & 20 & 16 & 8 & 0.8 & 5.2 \\
\hline HA 3 & $\mathrm{~T}$ & $\mathrm{SC}$ & 5 & 20 & 151 & 26 & 33 & 90 & 167 & 592 & 31 & 12 & 57 & 7 & 25 & 37 & 18 & 1.2 & 1.1 \\
\hline HA 4 & $\mathrm{~T}$ & $\mathrm{SC}$ & 4 & 16 & 63 & 10 & 14 & 79 & 91 & 408 & 16 & 11 & 243 & 6 & 17 & 13 & 20 & 0.8 & 0.8 \\
\hline HA 5 & $\mathrm{~T}$ & $\mathrm{SC}$ & 5 & 19 & 107 & 25 & 32 & 81 & 127 & 467 & 23 & 12 & 115 & 5 & 19 & 51 & 13 & 2.8 & 0.9 \\
\hline HA 6 & $\mathrm{~T}$ & SA & 3 & 14 & 59 & 8 & 10 & 86 & 75 & 661 & 13 & 10 & 98 & 4 & 15 & 14 & 24 & 0.6 & 0.7 \\
\hline HA 7 & $\mathrm{~T}$ & SA & 2 & 15 & 47 & 6 & 7 & 87 & 80 & 347 & 13 & 12 & 305 & 6 & 13 & 7 & 18 & 0.4 & 0.3 \\
\hline HA 9 & $\mathrm{~T}$ & SA & 3 & 13 & 38 & 6 & 8 & 79 & 65 & 556 & 11 & 8 & 112 & 4 & 10 & 40 & 20 & 3.3 & 2.8 \\
\hline HA 11 & $\mathrm{~T}$ & $\mathrm{SC}$ & 4 & 14 & 39 & 7 & 10 & 66 & 46 & 312 & 11 & 9 & 195 & 6 & 12 & 18 & 16 & 1.6 & 3.0 \\
\hline HA 14 & $\mathrm{~T}$ & SA & 3 & 13 & 38 & 6 & 8 & 79 & 65 & 556 & 11 & 8 & 112 & 4 & 10 & 40 & 20 & 3.3 & 2.8 \\
\hline \multirow[t]{4}{*}{ HA 15} & $\mathrm{~T}$ & SA & 2 & 15 & 47 & 6 & 7 & 87 & 80 & 347 & 13 & 12 & 305 & 6 & 13 & 7 & 18 & 0.4 & 0.3 \\
\hline & T-Avg & & 3 & 15 & 64 & 11 & 14 & 80 & 87 & 485 & 16 & 11 & 170 & 6 & 15 & 24 & 18 & 1.5 & 1.8 \\
\hline & Min & & 2 & 13 & 38 & 6 & 7 & 64 & 46 & 312 & 11 & 8 & 57 & 4 & 10 & 7 & 8 & 0.4 & 0.3 \\
\hline & Max & & 5 & 20 & 151 & 26 & 33 & 90 & 167 & 661 & 31 & 12 & 305 & 8 & 25 & 51 & 24 & 3.3 & 5.2 \\
\hline HA 2 & $\mathrm{Pt}$ & SC & 3 & 15 & 72 & 12 & 17 & 61 & 96 & 601 & 24 & 11 & 158 & 5 & 20 & 22 & 12 & 1.0 & 2.3 \\
\hline HA 8 & $\mathrm{Pt}$ & SC & 4 & 14 & 38 & 5 & 10 & 63 & 54 & 288 & 11 & 10 & 255 & 7 & 6 & 48 & 16 & 3.4 & 2.8 \\
\hline HA 10 & $\mathrm{Pt}$ & SC & 3 & 14 & 41 & 9 & 10 & 78 & 66 & 328 & 12 & 10 & 240 & 7 & 9 & 21 & 21 & 1.8 & 1.5 \\
\hline
\end{tabular}


Table 3 continued

\begin{tabular}{|c|c|c|c|c|c|c|c|c|c|c|c|c|c|c|c|c|c|c|c|}
\hline \multirow[t]{2}{*}{ Sample ID } & \multirow[t]{2}{*}{ Remark } & \multirow[t]{2}{*}{ Lithology } & \multicolumn{15}{|c|}{ Trace element $(\mathrm{mg} / \mathrm{kg})$} & \multicolumn{2}{|c|}{$(\mathrm{wt} \%)$} \\
\hline & & & As & $\mathrm{Pb}$ & $\mathrm{Zn}$ & $\mathrm{Cu}$ & $\mathrm{Ni}$ & $\mathrm{Cr}$ & $\mathrm{V}$ & $\mathrm{Sr}$ & $\mathrm{Y}$ & $\mathrm{Nb}$ & $\mathrm{Zr}$ & Th & $\mathrm{Sc}$ & $\mathrm{Br}$ & I & $\mathrm{Cl}$ & TS \\
\hline HA 12 & $\mathrm{Pt}$ & $\mathrm{SC}$ & 3 & 14 & 41 & 9 & 10 & 78 & 66 & 328 & 12 & 10 & 240 & 7 & 9 & 21 & 21 & 1.8 & 1.5 \\
\hline \multirow[t]{4}{*}{ HA 13} & $\mathrm{Pt}$ & $\mathrm{SC}$ & 3 & 14 & 41 & 9 & 10 & 78 & 66 & 328 & 12 & 10 & 240 & 7 & 9 & 21 & 21 & 1.8 & 1.5 \\
\hline & Pt-Avg & & 3 & 14 & 47 & 9 & 11 & 72 & 70 & 375 & 14 & 10 & 227 & 7 & 11 & 27 & 18 & 2.0 & 1.9 \\
\hline & Min & & 3 & 14 & 38 & 5 & 10 & 61 & 54 & 288 & 11 & 10 & 158 & 5 & 6 & 21 & 12 & 1.0 & 1.5 \\
\hline & $\operatorname{Max}$ & & 4 & 15 & 72 & 12 & 17 & 78 & 96 & 601 & 24 & 11 & 255 & 7 & 20 & 48 & 21 & 3.4 & 2.8 \\
\hline
\end{tabular}

TS total sulfur, $S C$ silt and clay, $S A$ sand

Inter-element relationships

As shown in Figs. 4 and 5, significant positive linear correlations exist between $\mathrm{Fe}_{2} \mathrm{O}_{3}$ and the trace metals, and between total sulfur and $\mathrm{Cl}, \mathrm{Br}, \mathrm{Fe}_{2} \mathrm{O}_{3}$ and $\mathrm{As}$ in Hikkaduwa lagoon tsunami sediments. Hambantota lagoon tsunami sediments show negative correlations between total sulfur with As and $\mathrm{Fe}_{2} \mathrm{O}_{3}$ may be due to mixing with non-marine beach sediments during the tsunami; positive linear correlations exist between
$\mathrm{Fe}_{2} \mathrm{O}_{3}$ and the trace metals, and between total sulfur with $\mathrm{Cl}$ and $\mathrm{Br}$. $\mathrm{Fe}_{2} \mathrm{O}_{3}$ is also positively correlated with $\mathrm{Cl}$ and $\mathrm{Br}$ and negatively correlated with iodine. Positive correlation between $\mathrm{Cl}$ and $\mathrm{Br}$ also occurs in the tsunami sediments (Hikkaduwa $R=0.89, n=17$; Hambantota $R=0.88$, $n=11)$, and both elements are negatively correlated with iodine (Hikkaduwa $\mathrm{Cl} R=-0.61, \mathrm{Br} R=-0.60, n=17$; Hambantota $\mathrm{Cl} R=-0.50, \mathrm{Br} R=-0.50, n=11)$. A strong positive correlation also exists between $\mathrm{Sr}$ and $\mathrm{CaO}$ in
Fig. 3 Average bulk concentrations of major oxides and trace elements in the surface sediments from Hikkaduwa and Hambantota lagoons.

a Normalized against average UCC composition (Rudnick and Gao 2005); data for local granitic gneiss and charnockite from Pohl and Emmermann (1991); b tsunami sediment average normalized against the pre-tsunami sediment average
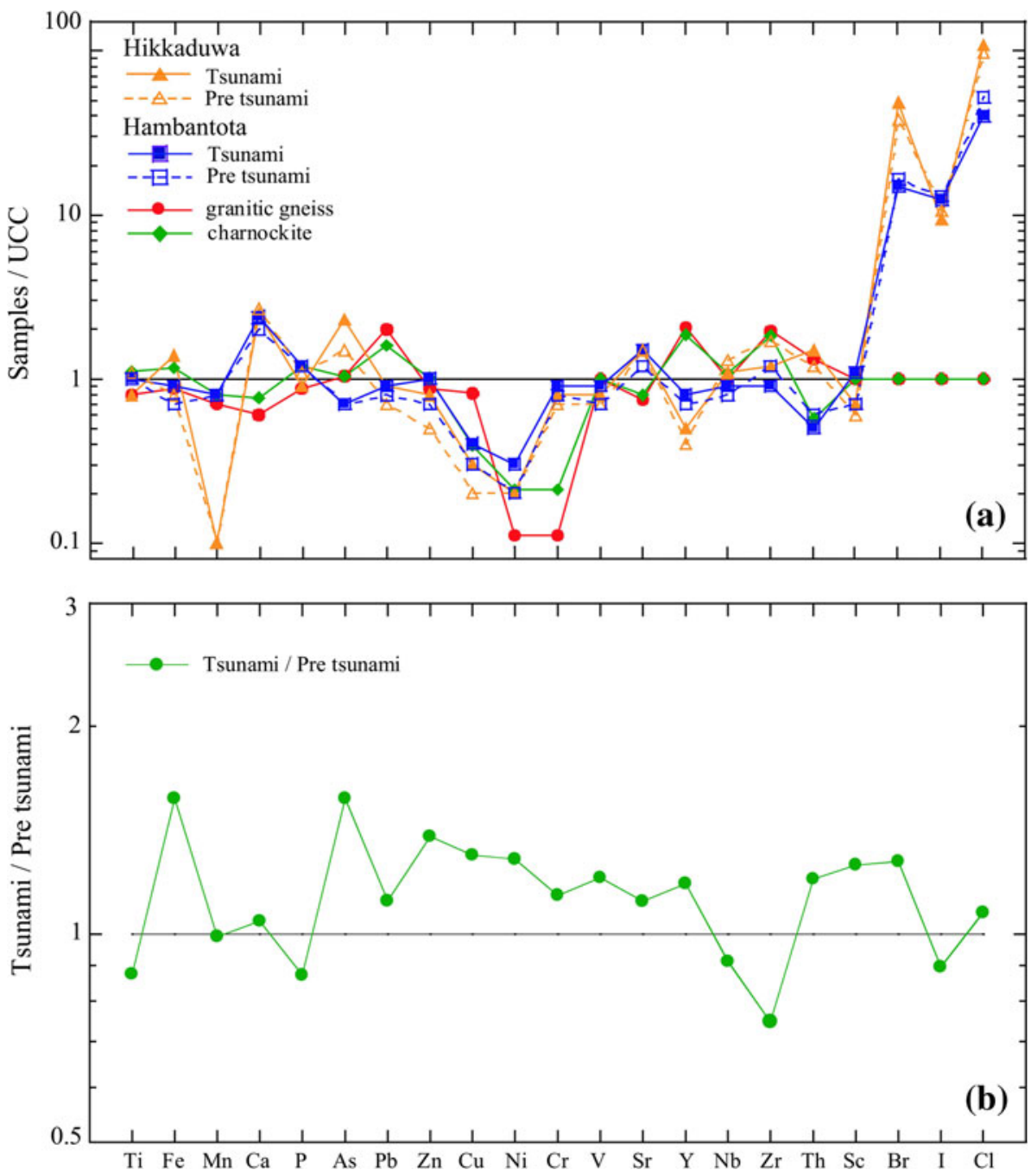
Fig. 4 Trace element (As, $\mathrm{Pb}$, $\mathrm{Zn}, \mathrm{Cu}, \mathrm{Ni}$ and $\mathrm{V})-\mathrm{Fe}_{2} \mathrm{O}_{3}$ variation diagrams for Hikkaduwa and Hambantota sediments. Fitted regressions are for the tsunami sediments in each lagoon
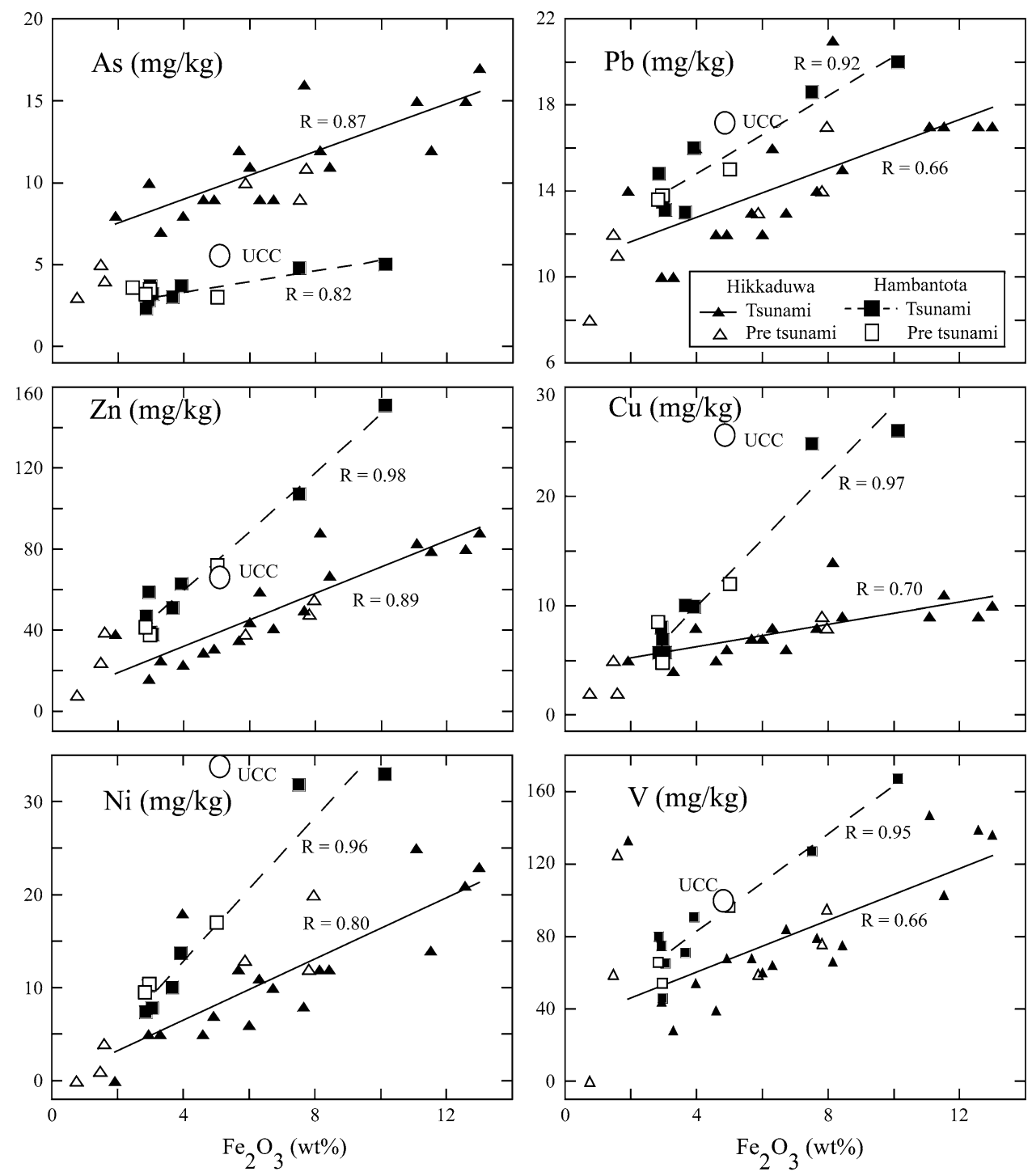

the tsunami sediments (Hikkaduwa $R=0.95, n=17$; Hambantota $R=0.68, n=11$ ), and both are weakly or negatively correlated with all other elements.

Principal component analysis of the tsunami sediments is illustrated in Fig. 6. The analysis was done using correlation matrix which obtained from geochemical data. Component 1 accounts for $42 \%$ of the variance, and which reflects the carbonate phase ( $\mathrm{CaO}$ and $\mathrm{Sr}$ ). This component shows negative loading for all other elements except $\mathrm{TiO}_{2}, \mathrm{Nb}, \mathrm{Zr}$, Th and Sc. This component suggested association of many shell fragments and heavy minerals with tsunami sediments. Principal component 2 accounts for $33 \%$ of the variance, and represents the association of $\mathrm{Cl}, \mathrm{Br}, \mathrm{As}, \mathrm{Th}, \mathrm{Fe}_{2} \mathrm{O}_{3}$ and total sulfur. Small positive loadings also occur for $\mathrm{Ca}$ and $\mathrm{Zr}$.

\section{Special features of the sediments}

Enrichment of most of the elements $\left(\mathrm{Fe}_{2} \mathrm{O}_{3}, \mathrm{Ca}, \mathrm{As}, \mathrm{Cl}, \mathrm{Br}\right.$ and total sulfur) typically associated with marine sediments in the pre-tsunami samples. This is possibly due to original lagoon peat and bog soils formed during the Holocene marine transgressions, with subsequent changes arising from variation in salinity produced by evaporation of lagoon water due to high temperatures, coupled with mixing with in situ sediments (Dahanayake 1982; Dissanayake 1984; Katupotha and Fujiwara 1988).

Higher values of $\mathrm{Cl}$ and $\mathrm{Br}$ in many tsunami sediments compared to the pre-tsunami sediments suggest that the former may have experienced higher salinity conditions than those prevailing in normal lagoon environments. Positive correlations of these elements with total sulfur suggest that their source was seawater (Dellwig et al. 2002). This further implies that $\mathrm{Cl}$ and $\mathrm{Br}$ enrichment is an intrinsic signature of tsunami sediments, and hence these elements have used to study tsunami, palaeosalinity, and sea level changes (Szczuciński et al. 2005; López-Buendía et al. 1999; Chagué-Goff et al. 2002). However, iodine is depleted in the tsunami sediments relative to the pre- 
Fig. 5 Correlations between total sulfur (TS) and $\mathrm{Cl}, \mathrm{Br}$, iodine, $\mathrm{Fe}_{2} \mathrm{O}_{3}$ and arsenic. Regressions are for the tsunami data in each lagoon. Circles anomalous values
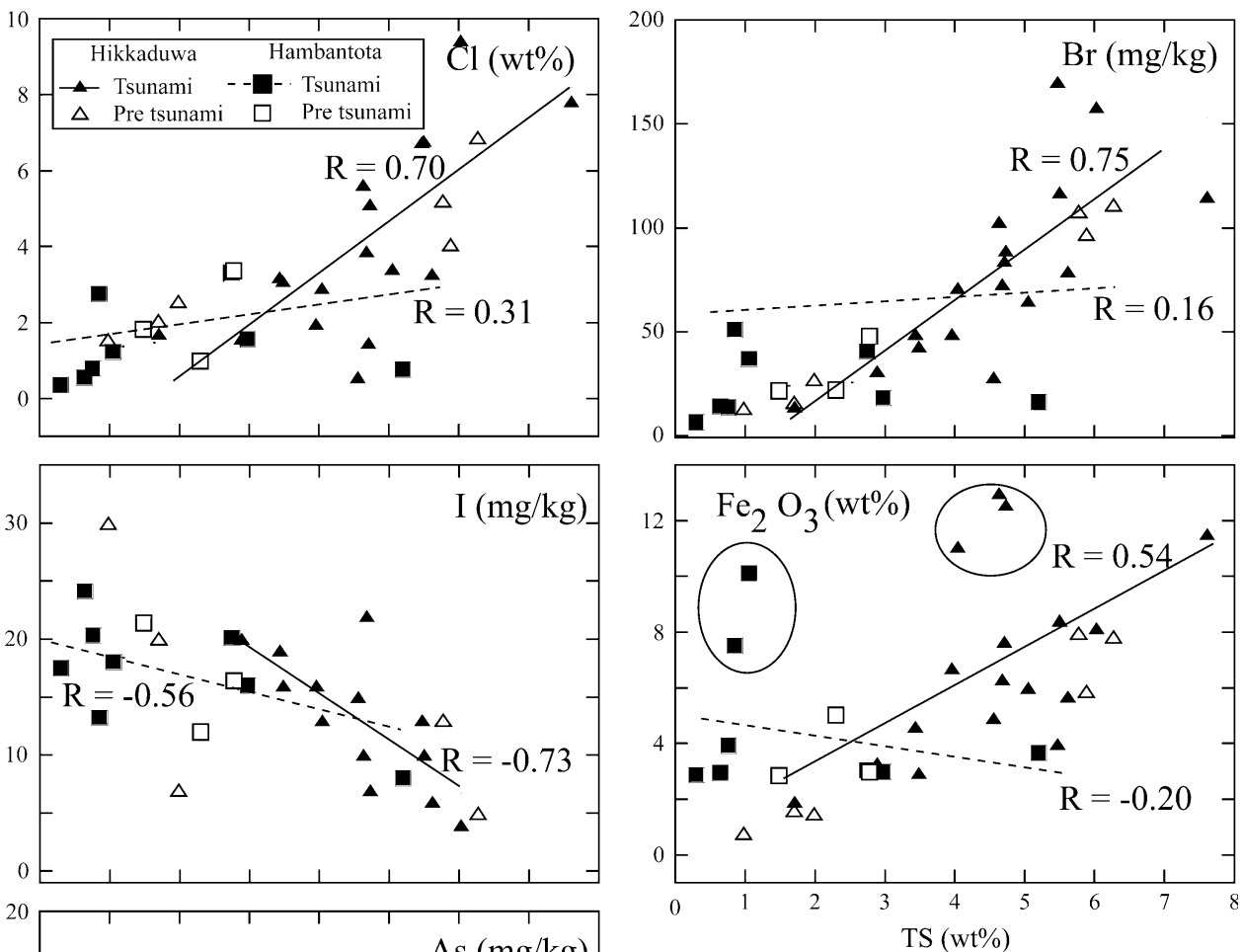

TS $(w t \%)$ tsunami deposits, and shows negative correlation with sulfur (Figs. 3b, 5). Iodine is generally enriched in marine organic matter, and can be released to water during the mineralization of organic substances (Ullman and Aller 1985; Muramatsu et al. 2007).

$\mathrm{CaO}$ and $\mathrm{Sr}$ are major components of marine sediments, as they are usually associated with carbonate phases (Plank and Langmuir 1998), and consequently these parameters have been used to distinguish tsunami sediments (Szczuciński et al. 2005; López-Buendía et al. 1999; Nichol et al. 2007). High $\mathrm{CaO}$ and $\mathrm{Sr}$ values in the tsunami sediments in the present study suggest strong marine influence in the source (Tables 2, 3). Positive loadings for these elements in principal component 1 (Fig. 6) emphasize that $\mathrm{CaO}$ and $\mathrm{Sr}$ are dominant over the other elements. Biogenic carbonate is highly enriched in continental shelf areas, and thus the tsunami sediments indicate they predominantly originated from a shallow marine environment. Average
$\mathrm{Sr} / \mathrm{Ca}$ ratio (0.0054) is similar to the average levels seen in continental shelf areas (Guebuem et al. 1999; Müller 1966; Yan and Tang 2009).

Sulfur and $\mathrm{Fe}_{2} \mathrm{O}_{3}$ have been effectively utilized to study Holocene sea level changes and tsunami sediments in many parts of the world, because they are useful indicators that reflect brackish or marine environmental changes in coastal wetland sediments (Goff and Chagué-Goff 1999; ChaguéGoff et al. 2000, 2002). The pronounced enrichment of sulfur (Hikkaduwa $4.4 \mathrm{wt} \%$, Hambantota $1.8 \mathrm{wt} \%$ ) in this study is greater than the average level $(0.3 \mathrm{wt} \%)$ in marine sediments (Berner 1970, 1982), suggesting that the sediments were deposited in marine conditions. The higher contents observed in tsunami sediments may be due to diffusion of sulfur into the sediments through reduction by sulfate bacteria under anoxic conditions developed by the abundant organic matter present. Sulfur also reacts with $\mathrm{Fe}_{2} \mathrm{O}_{3}$ in sediments and is fixed as $\mathrm{FeS}_{2}$ (Berner 1970, 
Fig. 6 Principal component analysis of the tsunami sediments to discriminate major components. Factors were determined by the Pearson's product-moment correlation matrix using Minitab 14 software

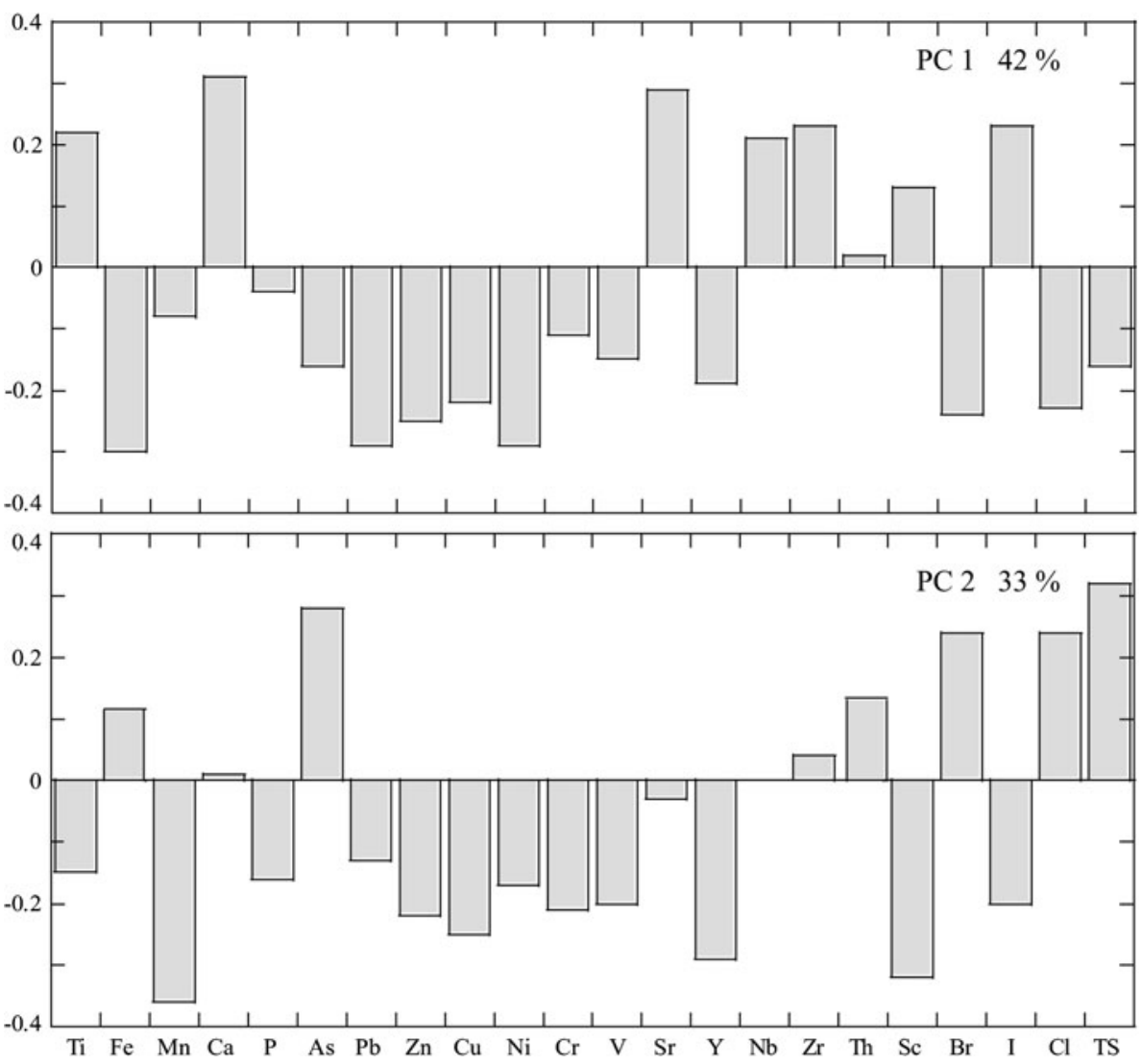

1982; Ishiga et al. 2000). The strong positive correlation between TS and $\mathrm{Fe}_{2} \mathrm{O}_{3}$ in Hikkaduwa lagoon (Fig. 5) thus suggest that the higher sulfur and $\mathrm{Fe}_{2} \mathrm{O}_{3}$ concentrations in the tsunami sediments are predominantly due to pyrite formation (Berner 1970). However, Hambantota lagoon shows negative correlation due to lower abundances of TS and $\mathrm{Fe}_{2} \mathrm{O}_{3}$ due to mixing of tsunami sediments with nonmarine sediments during the tsunami.

Abundances of $\mathrm{As}, \mathrm{Pb}, \mathrm{Zn}, \mathrm{Cu}$ and $\mathrm{Ni}$ in the tsunami sediments are high relative to the pre-tsunami deposits (Table 3; Fig. 3b). All these elements are closely associated with sulfur and have positive linear correlations with $\mathrm{Fe}_{2} \mathrm{O}_{3}$. This implies that they are also predominantly fixed as sulfides under anoxic conditions within the sediments (Ishiga et al. 2000; Bibi et al. 2006). The results of this study show that trace element correlations with $\mathrm{Fe}_{2} \mathrm{O}_{3}$ and/or sulfur are also useful chemical parameters for identifying tsunami deposits. However, arsenic is regarded as the most suitable indicator element for such studies due to enrichment in anoxic condition and seawater (Szczuciński et al. 2005; Chagué-Goff et al. 2002). High abundances of $\mathrm{Pb}, \mathrm{Zn}, \mathrm{Cu}$ and $\mathrm{Ni}$ seen in this study are also useful indicators, because these elements are relatively abundant in seawater and marine sediments (Dellwig et al. 2002).
Possible sources of the sediments

Tsunami sediments from Hikkaduwa lagoon show a scattered distribution on a Th-Sc-Zr/10 plot (Fig. 7a). The data lie toward to the $\mathrm{Zr}$-Th edge and plot away from the value of sediments around the subduction zone (Plank and Langmuir 1998) in Sumatra where the tsunami waves originated (Fig. 7a). In contrast, Hambantota tsunami sediments show a flat-lying trend with variable $\mathrm{Sc} / \mathrm{Zr}$, trending differently from Hikkaduwa equivalents (Fig. 7a). However, some tsunami sediments also plot with the pretsunami samples, residual soils, marsh sediments, and basement rocks.

Hikkaduwa tsunami sediments have high $\mathrm{Th} / \mathrm{Sc}$ and $\mathrm{Zr} /$ Sc ratios, plotting between the values typical of Phanerozoic granites, felsic volcanic rocks, and upper continental crust (Fig. 7b), thus indicating derivation from felsic source rocks. The variable $\mathrm{Zr} / \mathrm{Sc}$ ratios and trend across the primary compositional trend reflects sorting and concentration of heavy minerals in both the tsunami and pre-tsunami sediments. Higher abundances of $\mathrm{Sc}$ in the Hambantota sediments suggest that their source was richer in mafic minerals (McLennan et al. 1993; Roser 2000), and may provide additional evidence for the association of such minerals in tsunamigenic sediments (Moore et al. 2007; 

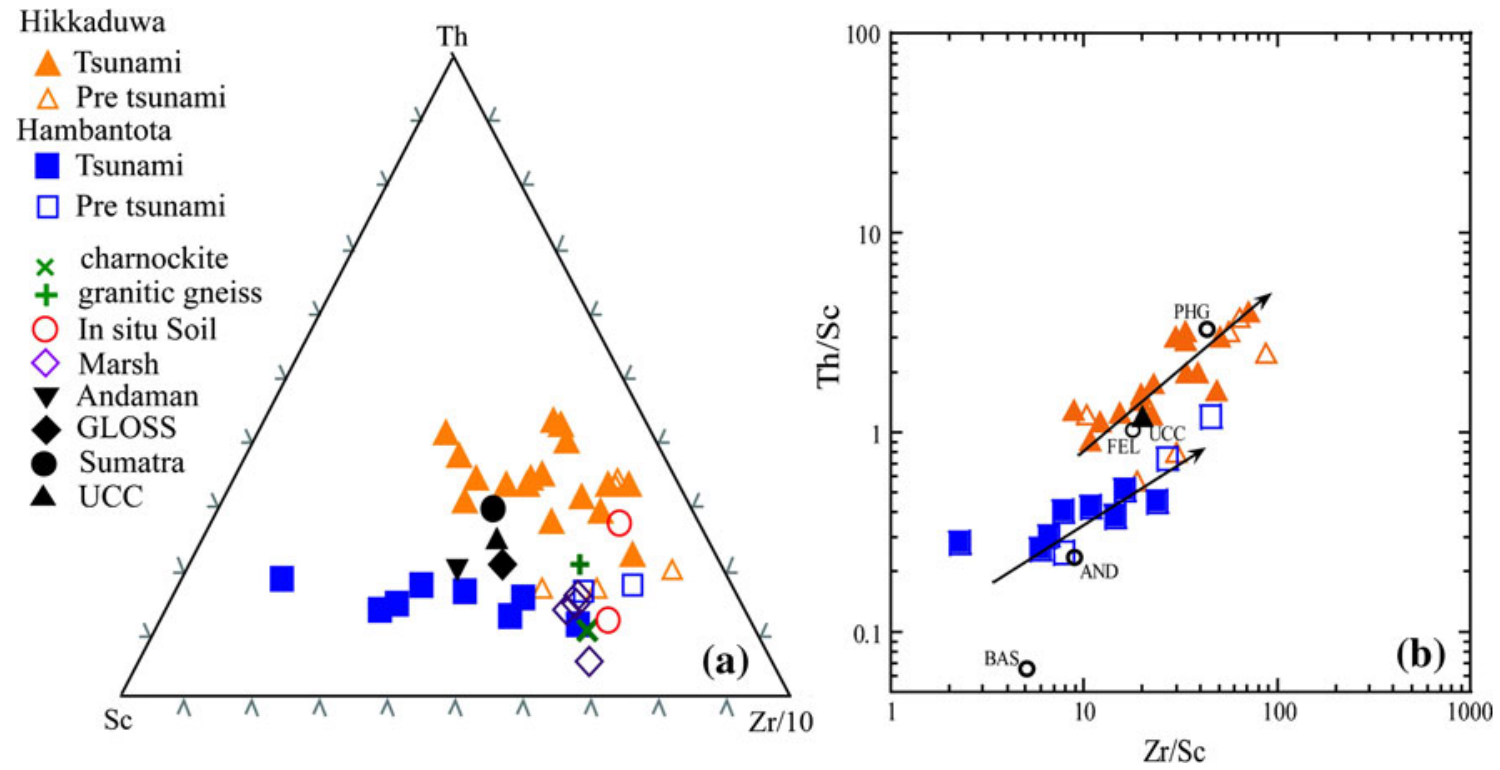

Fig. 7 a Th-Sc-Zr/10 plot (Bhatia and Crook 1986) for Hikkaduwa and Hambantota lagoon sediments and reference samples from soils and marsh lands (this study); charnockite and granitic gneiss (Pohl and Emmermann 1991); Andaman, Sumatra, and GLOSS sediment (Plank and Langmuir 1998), UCC (Rudnick and Gao 2005); b Th/Sc-
$\mathrm{Zr} / \mathrm{Sc}$ plot (McLennan et al. 1993; after Roser 2000). Circles igneous rock averages from Condie (1993); $P H G$ phanerozoic granite; FEL, $A N D, B A S$ mesozoic-cenozoic felsic volcanic rock, andesite, and basalt, respectively

of Hambantota lagoon water was 9.3. This may be coupled to phytoplankton photosynthesis, because the photosynthetic process consumes $\mathrm{CO}_{2}\left(\mathrm{HCO}_{3}-\right)$ and releases $\mathrm{O}_{2}$ to the water, increasing DO (average $8.8 \mathrm{mg} / \mathrm{l}$ ). However, Hikkaduwa lagoon lacks phytoplankton, thus lowering DO $(3.5 \mathrm{mg} / \mathrm{l})$. Production of carbonic acid due to decomposition of organic matter hence maintains the average $\mathrm{pH}$ around 7.6 (Lopes and Silva 2006). Moreover, the bottom water turbidity in water overlying organic matter-rich tsunami sediments in both lagoons is an intrinsic signature of microbial activities within the sediment (ThieBen et al. 2006). The salinity, conductivity and TDS of the lagoons show a brackish condition, although the values are much lower than those of seawater. In both lagoons, vertical variation of these parameters is insignificant (Table 1). This feature may be due to poor connection with the sea through narrow channels, or the particular morphological characteristics of each lagoon, which minimize seawater influence. The small tidal range around Sri Lanka may also be a contributing factor (Wijeratne and Rydberg 2007; Wijeratne and Pattiaratchi-web reference). Moreover, halogen compounds in sediments can create possible environmental effects, especially on the salinity of associated water bodies, because such compounds can freely dissolve in water due to their higher electronegativity and lesser redox sensitivity (Muramatsu et al. 2007; Killops and Killops 2005). 
Physico-chemical measurements showed both the tsunami and pre-tsunami sediments had neutral $\mathrm{pH}$ and negative ORP. The negative ORP implies that the sediments were undergoing organic mineralization. In this process, oxygen in the system is reduced by sulfate-reducing and methane-producing bacteria, especially under negative ORP conditions at the surface of the sediments $(5-20 \mathrm{~cm}$ depth) where highly active sulfate-reducing bacteria release $\mathrm{H}_{2} \mathrm{~S}$ to the lagoon water (Meyers et al. 1996; Killops and Killops 2005).

Role of tsunami waves on sedimentation

The higher organic matter contents of the tsunami sediments in both lagoons suggest that they were predominantly brought from a shallow marine environment, due to the high primary production in that zone (Killops and Killops 2005). The process of near-shore tsunami wave propagation may also contribute to more effective collection of organic matter from continental shelves rather than from slope or deep marine environments. Tsunami waves travel throughout the water column at equal velocity, but when they reach the continental slope deeper waves are obstructed and move upwards at lower velocity, while the velocity of the surface waves remains the same (Weiss 2008). Organic matter contents of Hikkaduwa lagoon tsunami sediments are relatively high. This may be due to stronger wave impact in the southwestern district than in the south, and variation of morphology of the continental shelf. A greater volume of OM-rich sediments may therefore have been transported from continental shelf and slope marine environments to Hikkaduwa lagoon (Weiss 2008). The lower abundances in Hambantota lagoon may have been controlled by lesser wave action, and hence greater contribution from shallow marine sediments and coastal sands.

\section{Conclusions}

Geochemical investigation of tsunami and pre-tsunami sediments reveal compositional contrasts. Tsunami sediments contain higher abundances of $\mathrm{Cl}, \mathrm{Br}, \mathrm{As}, \mathrm{Fe}$ and total sulfur reflecting higher salinity and stronger marine influence. Higher values of $\mathrm{Ca}$ and $\mathrm{Sr}$ associated with OM-rich sediments are attributed to biogenic phases of shallow marine origin. Immobile element abundances and ratios indicate that the tsunami sediments were predominantly derived from a felsic source containing some mafic assemblages, further influenced by heavy mineral concentration and sorting. The compositional variations in the tsunami sediments according to the location are predominantly due to variation of wave strength, morphology of the continental shelf, and composition of local source rocks, reflected in the differing compositions in Hikkaduwa and Hambantota lagoons.

The physico-chemical properties of the lagoon waters suggest that there is significant influence from OM-rich tsunami sediments on oxidation-reduction potential of the bottom water, leading to the prevalence of strongly anoxic conditions and favorable conditions for mobility of redoxsensitive elements from the sediments to the lagoon water. This especially provides a favorable environment for anaerobic bacteria, promoting sulfate reduction and methane production.

Acknowledgments The authors thank Professor Yoshihiro Sawada of Shimane University for access to the XRF facilities. Dr. Barry Roser of Shimane University and two anonymous reviewers are acknowledged for their constructive comments on an earlier draft, which improved the manuscript considerably. Authors also acknowledge the head of the Department of Geology and the staff of Peradeniya University for their support during sampling and for providing laboratory facilities. This study was supported by a Japanese government MEXT (Monbukagakusho) graduate scholarship to DTJ.

\section{References}

Ahmed F, Bibi MH, Monsur MH, Ishiga H (2005) Present environment and historic changes from the record of lake sediments, Dhaka city, Bangladesh. Environ Geol 48(1):25-36

Berner RA (1970) Sedimentary pyrite formation. Am J Sci 268(1): $1-23$

Berner RA (1982) Burial of organic carbon and pyrite sulfur in the modern ocean: its geochemical and environmental significance. Am J Sci 282(1-4):451-473

Bhatia MR, Crook KAW (1986) Trace element characteristics of graywackes and tectonic setting discrimination of sedimentary basins. Contrib Mineral Petr 92(2):181-193

Bibi MH, Ahmed F, Ishiga H (2006) Distribution of arsenic and other trace elements in the Holocene sediments of the Meghna River Delta, Bangladesh. Environ Geol 50(8):1243-1253

Chagué-Goff C, Nichol SL, Jenkinson AV, Heijnis H (2000) Signatures of natural catastrophic events and anthropogenic impact in an estuarine environment, New Zealand. Mar Geol 167(3-4):285-301

Chagué-Goff C, Dawson S, Goff JR, Zachariasen J, Berryman KR, Garnett DL, Waldron HM, Mildenhall DC (2002) A tsunami (ca. 6,300 years BP) and other Holocene environmental changes, northern Hawke's Bay, New Zealand. Sediment Geol 150(1-2):89-102

Condie KC (1993) Chemical composition and evolution of the upper continental crust: contrasting results from surface samples and shales. Chem Geol 104(1):1-37

Crowley SF, Stow DAV, Croudace IW (1998) Mineralogy and geochemistry of Bay of Bengal deep-sea fan sediments, ODP Leg 116: evidence for an Indian subcontinent contribution to distal fan sedimentation. Geol Soc Lond Spec Pub 131(1):151-176

Dahanayake K (1982) Laterites of Sri Lanka-a reconnaissance study. Miner Deposita 17(2):245-256

Dahanayake K, Kulasena N (2008) Recognition of diagnostic criteria for recent- and paleo-tsunami sediments from Sri Lanka. Mar Geol 254(3-4):180-186 
Dellwig O, Böttcher ME, Lipinski M, Brumsack H (2002) Trace metals in Holocene coastal peats and their relation to pyrite formation (NW Germany). Chem Geol 182(2-4):423-442

Dissanayake CB (1984) Geochemistry of the Muthurajawela peat deposit of Sri Lanka. Fuel 63(11):1494-1503

Goff JR, Chagué-Goff C (1999) A late Holocene record of environmental changes from coastal wetlands: Abel Tasman National Park, New Zealand. Quatern Int 56(1):39-51

Guebuem K, Yang H, Church TM (1999) Geochemistry of alkaline earth elements $(\mathrm{Mg}, \mathrm{Ca}, \mathrm{Sr}, \mathrm{Ba})$ in the surface sediments of the Yellow Sea. Chem Geol 153(1):1-10

Gurung JK, Ishiga H, Khadka MS (2005) Geological and geochemical examination of arsenic contamination in groundwater in the Holocene Terai Basin, Nepal. Environ Geol 49(1):98-113

Ishiga H, Nakamura T, Sampei Y, Tokuoka T, Takayasu K (2000) Geochemical record of the Holocene Jomon transgression and human activity in coastal lagoon sediments of the San' in district SW Japan. Global Planet Change 25(3-4):223-237

Katupotha J, Fujiwara K (1988) Holocene sea level change on the southwest and south coasts of Sri Lanka. Palaeogeogr Palaeocl 68(2-4):189-203

Killops S, Killops V (2005) Introduction to organic geochemistry. Blackwell, Oxford, pp 71-80, 97

Lopes JF, Silva C (2006) Temporal and spatial distribution of dissolved oxygen in the Ria de Aveiro lagoon. Ecol Model 197(1-2):67-88

López-Buendía AM, Bastida J, Querol X, Whateley MKG (1999) Geochemical data as indicators of palaeosalinity in coastal organic-rich sediments. Chem Geol 157(3-4):235-254

Markou DA, Sylaios GK, Tsihrintzis VA, Gikas GD, Haralambidou K (2007) Water quality of Vistonis lagoon, northern Greece: seasonal variation and impact of bottom sediments. Desalination 210(1-3):83-97

McLennan SM, Hemming S, McDaniel DK, Hanson GN (1993) Geochemical approaches to sedimentation, provenance and tectonics. Geol Soc Amer Spec Paper 284(1):21-40

Meyers PA, Silliman JE, Shaw TJ (1996) Effects of turbidity flows on organic matter accumulation, sulfate reduction, and methane generation in deep-sea sediments on the Iberia Abyssal Plain. Org Geochem 25(1-2):69-78

Minoura K, Nakaya S, Uchida M (1994) Tsunami deposits in a lacustrine sequence of the Sanriku coast, northeast Japan. Sediment Geol 89(1-2):25-31

Moore AL, McAdoo BG, Ruffman A (2007) Landward fining from multiple sources in a sand sheet deposited by the 1929 Grand Banks tsunami, Newfoundland. Sediment Geol 200(3-4):336346

Morton RA, Goff JR, Nichol SL (2008) Hydrodynamic implications of textural trends in sand deposits of the 2004 tsunami in Sri Lanka. Sediment Geol 207(1-4):56-64

Müller G (1966) Grain size, carbonate content, and carbonate mineralogy of recent sediments of the Indian Ocean off the eastern coast of Somalia. Naturwissenschaften 53(21):547-550

Muramatsu Y, Doi T, Tomaru H, Fehn U, Takeuchi R, Matsumoto R (2007) Halogen concentrations in pore waters and sediments of the Nankai Trough, Japan: implications for the origin of gas hydrates. Appl Geochem 22(3):534-556

Nichol SL, Goff JR, Devoy RJN, Chagué-Goff C, Hayward B, James I (2007) Lagoon subsidence and tsunami on the west coast of New Zealand. Sediment Geol 200(3-4):248-262
Nishimura Y, Miyaji N (1995) Tsunami deposits from the 1993 southwest Hokkaido earthquake and the 1640 Hokkaido Komagatake eruption, northern Japan. Pure Appl Geophys 144(3-4):719-733

Othman DB, White WM, Patchett J (1989) The geochemistry of marine sediments, island arc magma genesis, and crust-mantle recycling. Earth Planet Sci Lett 94(1-2):1-21

Paris R, Lavigne F, Wassmer P, Sartohadi J (2007) Coastal sedimentation associated with the December 26, 2004 tsunami in Lhok Nga, west Banda Aceh (Sumatra, Indonesia). Mar Geol 238(1-4):93-106

Pattan JN, Shane P (1999) Excess aluminum in deep sea sediments of the central Indian basin. Mar Geol 161(2-4):247-255

Plank T, Langmuir CH (1998) The chemical composition of subducting sediment and its consequences for the crust and mantle. Chem Geol 145(3-4):325-394

Pohl JR, Emmermann R (1991) Chemical composition of the Sri Lankan Precambrian basement. In: Kroner A (ed) The crystalline crust of Sri Lanka, part 1, summary of research of the GermanSri Lankan consortium. Geological Survey Department Sri Lanka Paper vol 7, pp 94-124

Roonwal GS, Glasby GP, Chugh R (1997) Mineralogy and geochemistry of surface sediments from the Bengal Fan, Indian Ocean. J Asian Earth Sci 15(1):33-41

Roser BP (2000) Whole-rock geochemical studies of clastic sedimentary suites. Mem Geol Soc Japan 57(1):73-89

Rudnick RL, Gao S (2005) Composition of the continental crust. In: Rudnick RL (ed) The Crust. Holland HD, Turekian KK (eds) Treatise on Geochemistry, vol 3, Elsevier-Pergamon, Oxford, pp $17-18$

Shi S, Dawson AG, Smith DE (1995) Coastal sedimentation associated with the December 12th, 1992 tsunami in Flores, Indonesia. Pure Appl Geophys 144(3-4):525-536

Szczuciński W, Niedzielski P, Rachlewicz G, Sobczyński T, Ziola A, Kowalski A, Lorenc S, Siepak J (2005) Contamination of tsunami sediments in a coastal zone inundated by the 26 December 2004 tsunami in Thailand. Environ Geol 49(2):321331

Taylor SR, McLennan SM (1985) The continental crust: its composition and evolution. Blackwell, Oxford, pp 45-51

ThieBen O, Schmidt M, Theilen F, Schmitt M, Klein G (2006) Methane formation and distribution of acoustic turbidity in organic-rich surface sediments in the Arkona Basin, Baltic Sea. Cont Shelf Res 26(19):2469-2483

Ullman WJ, Aller RC (1985) The geochemistry of iodine in nearshore carbonate sediments. Geochim Cosmochim Acta 49(4):967-978

Weiss R (2008) Sediment grains moved by passing tsunami waves: tsunami deposits in deep water. Mar Geol 250(3-4):251-257

Wijayananda NP (1994) A note on the continental shelf sediments around Sri Lanka. J Geol Soc Sri Lanka 5(1):135-139

Wijeratne EMS, Rydberg L (2007) Modelling and observations of tidal waves propagation, circulation and residence times in Puttalam lagoon, Sri Lanka. Estuar Coast Shelf S 74(4):697-708

Yan Z, Tang D (2009) Changes in suspended sediments associated with 2004 Indian Ocean tsunami. Adv Space Res 43(1):89-95

Zhang X, Tang D, Li Z, Zhang F (2009) The effects of wind and rainfall on suspended sediment concentration related to the 2004 Indian Ocean tsunami. Mar Pollut Bull 58(9):1367-1373 